\title{
Open versus hybrid versus totally minimally invasive Ivor Lewis esophagectomy: Systematic review and meta-analysis
}

\author{
Camila Bras Harriott, MD, ${ }^{\mathrm{a}}$ Cristian A. Angeramo, MD, ${ }^{\mathrm{a}}$ María A. Casas, MD, ${ }^{\mathrm{a}}$ and \\ Francisco Schlottmann, MD, MPH ${ }^{\mathrm{a}, \mathrm{b}}$
}

\section{ABSTRACT}

Background: Hybrid and minimally invasive approaches have emerged as less invasive alternatives to open Ivor Lewis esophagectomy. The aim of this study was to compare surgical outcomes between open (OE), hybrid (HE), and totally minimally invasive esophagectomy (TMIE).

Methods: A systematic literature search was performed to analyze outcomes after $\mathrm{OE}, \mathrm{HE}$, and TMIE with intrathoracic anastomosis. Main outcomes included anastomotic leak rate, overall morbidity, and 30-day mortality. A meta-analysis of proportions was used to assess the effect of each approach on different outcomes.

Results: A total of 130 studies comprising 16,053 patients were included for analysis; $8081(50.3 \%)$ underwent OE, $1524(9.5 \%) \mathrm{HE}$, and 6448 (40.2\%) TMIE. The risk of anastomotic leak was lower after OE (odds ratio [OR], $0.71 ; 95 \% \mathrm{Cl}, 0.62-0.81$; $P<.0001)$. Overall morbidity rate was $45 \%(95 \% \mathrm{Cl}, 38 \%-52 \%)$ after OE, $40 \%$ ( $95 \% \mathrm{Cl}, 25 \%-59 \%)$ after $\mathrm{HE}$, and $37 \%(95 \% \mathrm{Cl}, 32 \%-43 \%)$ after TMIE. Risk estimation showed higher odds of postoperative mortality after $\mathrm{OE}(\mathrm{OR}, 2.22 ; 95 \% \mathrm{Cl}$, 1.76-2.81; $P<.0001)$ and $\mathrm{HE}(\mathrm{OR}, 1.93 ; 95 \% \mathrm{Cl}, 1.32-2.81 ; P<.001)$, compared with TMIE. Median length of hospital stay (LOS) was 14.1 (range, 8-28), 12.5 (range, 8-18), and 11.9 (range, 7-30) days after OE, HE and TMIE, respectively $(P=.003)$.

Conclusions: HE and TMIE are associated with lower rates of overall morbidity, reduced postoperative mortality, and shorter LOS, compared with OE. TMIE is associated with lower mortality rates and shorter LOS than HE. Further efforts are needed to widely embrace TMIE in a safe manner. (J Thorac Cardiovasc Surg 2022;164:e233-54)

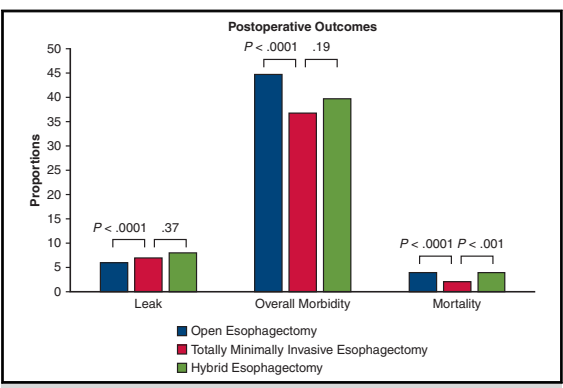

Surgical outcomes; comparison of open, hybrid and minimally invasive Ivor Lewis approaches.

\section{CENTRAL MESSAGE}

Totally minimally invasive esophagectomy is associated with reduced postoperative mortality and shorter length of hospital stay, compared with open and hybrid esophagectomy.

\section{PERSPECTIVE}

A comprehensive analysis of reported outcomes after Ivor Lewis esophagectomy was done. Totally minimally invasive esophagectomy was associated with lower rates of overall morbidity, postoperative mortality, and shorter hospital stay, compared with open esophagectomy. Also, totally minimally invasive esophagectomy was associated with lower rates of mortality and shorter hospital stay than hybrid esophagectomy.

See Commentary on page e255. $\rightarrow$ Video clip is available online.

From the ${ }^{\mathrm{a}}$ Department of Surgery, and ${ }^{\mathrm{b}}$ Division of Esophageal and Gastric Surgery, Hospital Alemán of Buenos Aires, Buenos Aires, Argentina.

Received for publication Sept 6, 2021; revisions received Dec 3, 2021; accepted for publication Dec 24, 2021; available ahead of print Jan 18, 2022.

Address for reprints: Francisco Schlottmann, MD, MPH, Department of Surgery, Hospital Aleman of Buenos Aires, Av Pueyrredon 1640, Buenos Aires, Argentina (E-mail: fschlottmann@hotmail.com). 


\section{Abbreviations and Acronyms \\ $\mathrm{HE}$ = hybrid esophagectomy \\ IRB = institutional review board \\ LOS = length of hospital stay \\ $\mathrm{OE}=$ open esophagectomy \\ $\mathrm{OR}=$ odds ratio \\ TMIE $=$ totally minimally invasive esophagectomy}

of incidence and sixth in overall mortality. ${ }^{3}$ Although esophageal squamous cell carcinoma is the most prevalent histological type worldwide, a increasing prevalence of esophageal adenocarcinoma has been reported in Western countries. ${ }^{4,5}$

Esophagectomy is a fundamental mainstay for esophageal cancer treatment. ${ }^{6}$ The Ivor Lewis technique, which was first described in 1946, originally involved a laparotomy and right thoracotomy with an intrathoracic anastomosis. ${ }^{7}$ Since the introduction of endoscopic subtotal esophagectomy using a right thoracoscopic approach in $1992,{ }^{8}$ minimally invasive surgery has been embraced by several centers in the past 2 decades. ${ }^{9-14}$ However, because a totally minimally invasive transthoracic esophagectomy is a challenging and demanding procedure, some esophageal surgeons still perform open (OE) or hybrid esophagectomy (HE) ${ }^{15-20}$ The aim of this systematic review and meta-analysis was to compare surgical outcomes between $\mathrm{OE}$, HE, and totally minimally invasive Ivor Lewis esophagectomy (TMIE).

\section{METHODS \\ Data Sources}

A systematic literature review of articles on $\mathrm{OE}, \mathrm{HE}$, and totally minimally invasive esophagectomy (TMIE) was performed according to the Preferred Reporting Items for Systematic Reviews and Meta-Analyses guidelines. An electronic search in the Medline database was performed using the following key terms: "Ivor Lewis," "Transthoracic esophagectomy," "Laparoscopy," "Thoracoscopy," "Robotic," "Minimally invasive esophagectomy," "Minimally invasive esophageal surgery," and "Robotassisted esophagectomy." The institutional review board (IRB) approved this study (IRB approval by Hospital Alemán of Buenos Aires on May 10, 2021. Systematic review and meta-analyses are approved by the IRB of our institution without need for IRB approval number).

\section{Study Selection and Data Extraction}

Eligible studies included those that analyzed outcomes for patients who underwent OE, HE, and TMIE. Only patients with an intrathoracic anastomosis were included. OE was defined as laparotomy with thoracotomy. HE was defined as either laparoscopy with thoracotomy or laparotomy with thoracoscopy. TMIE included patients who underwent laparoscopic with thoracoscopic or robot-assisted esophagectomy.

The search strategy was restricted to studies on humans, reported in English, and published between 2000 and 2020. The titles and abstracts identified in the literature search were independently screened by 2 reviewers (C.B.H. and C.A.A.). For studies that included different types of approach (eg, OE, HE, and TMIE) in the same publication, only those that reported outcomes for each subgroup of patients were included for analysis. In cases in which multiple publications used an overlapping pool of patients, only the larger studies were included.

A total of 4467 articles were initially screened. After removing duplicates and articles that did not meet the inclusion criteria, 4401 articles were reviewed by both authors on the basis of the methodological quality of the publications. Discrepancies between the 2 reviewers were resolved by discussion and consensus with the senior author (F.S.). Finally, 130 articles were included for the meta-analysis. The flow chart on the selection of studies is shown in Figure E1.

The data were carefully evaluated and extracted independently from all of the eligible publications. Information retrieved from the studies included author, publication year, study design, population size, demographic variables, use of neoadjuvant therapy, surgical approach, operative time, anastomotic leak rate, overall morbidity, pneumonia, arrhythmia, mortality, and length of hospital stay (LOS).

Mortality was defined as death before discharge from hospital or within the first 30 postoperative days. From the 130 studies that reported anastomotic leakage rates, 62 defined the diagnosis of anastomotic leak on the basis of at least 1 of the following: radiographic findings, clinical symptoms, endoscopy, methylene blue test, or operative finding. ${ }^{21-25, E 1-E 56, E 140}$ The remaining 68 studies did not report how the anastomotic leak was defined or diagnosed. ${ }^{10, \text { E57-E122,E141 }}$

\section{Main Outcomes and Measures}

Main outcomes included anastomotic leak rate, overall morbidity, and mortality. Secondary end points included operative time, pneumonia, arrhythmia, and LOS.

\section{Statistical Analysis}

The occurrence rate (pooled proportion) and $95 \%$ CI were calculated for anastomotic leak rate, overall morbidity, and mortality. Using an a priori assumption of significant heterogeneity, a random effect model was used to estimate pooled proportions and $95 \%$ CI. Statistical heterogeneity was assessed using the $I^{2}$ statistic, and significance was assumed when the $I^{2}$ was greater than $50 \%$. Heterogeneity was also defined as a Cochran $\mathrm{Q}<0.10$. The summary statistics were treated as independent observations and analyzed using standard methods for independent data. Mean age and mean operative time were compared for patients who underwent $\mathrm{OE}$, HE, and TMIE using the Kruskal-Wallis test. Linear regression was used to model the effect of each approach on the different main outcomes and secondary end points. The parameter for the procedure from the linear model (ie, the log odds ratio in a comparison the 3 approaches) describes differences between groups (TMIE as reference group).

For the main outcomes, publication bias was investigated using funnel plots and the rank correlation test. We used R version 4.1.2 (R Project for Statistical Computing) with meta and metafor packages for all analyses. Statistical tests were 2 -sided.

\section{RESULTS}

A total of 16,053 patients were included for analysis; $8081(50.3 \%)$ underwent OE, $1524(9.5 \%) \mathrm{HE}$, and 6448 $(40.2 \%)$ TMIE. Mean operative time was shorter among patients who underwent $\mathrm{OE}$ (OE, 286.1 vs HE, 339.3 vs TMIE, 355.6 minutes; $P=.0001$ ). Patient characteristics are summarized in Tables E1, E2, and E3.

The pooled proportion of anastomotic leak was $6 \%$ (95\% CI, 5\%-7\%) after OE, 8\% (95\% CI, 6\%-11\%) after 


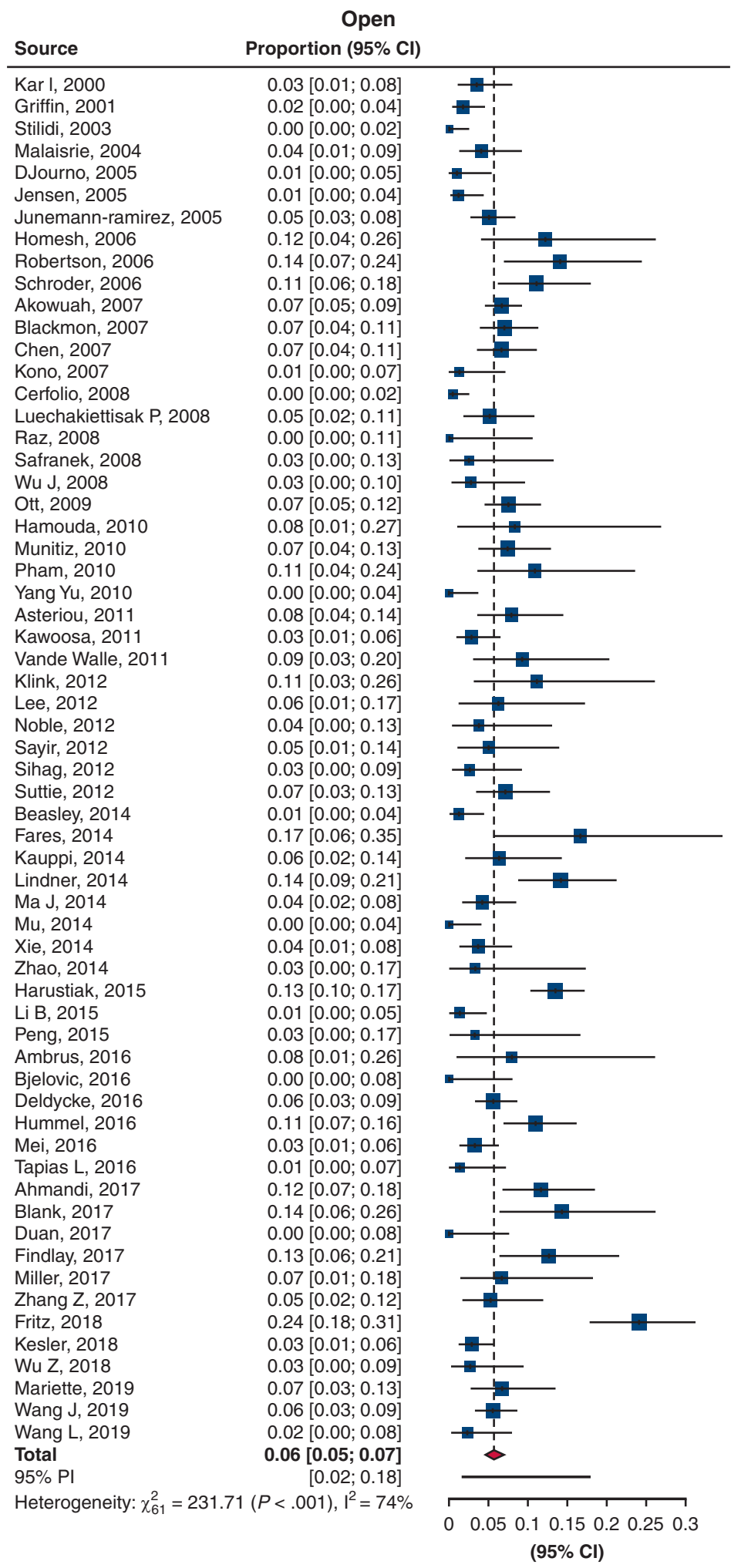

FIGURE 1. Proportion forest plots of anastomotic leak in open, hybrid, and totally minimally invasive Ivor Lewis esophagectomy. $C I$, Confidence interval; $P I$, prediction interval. 


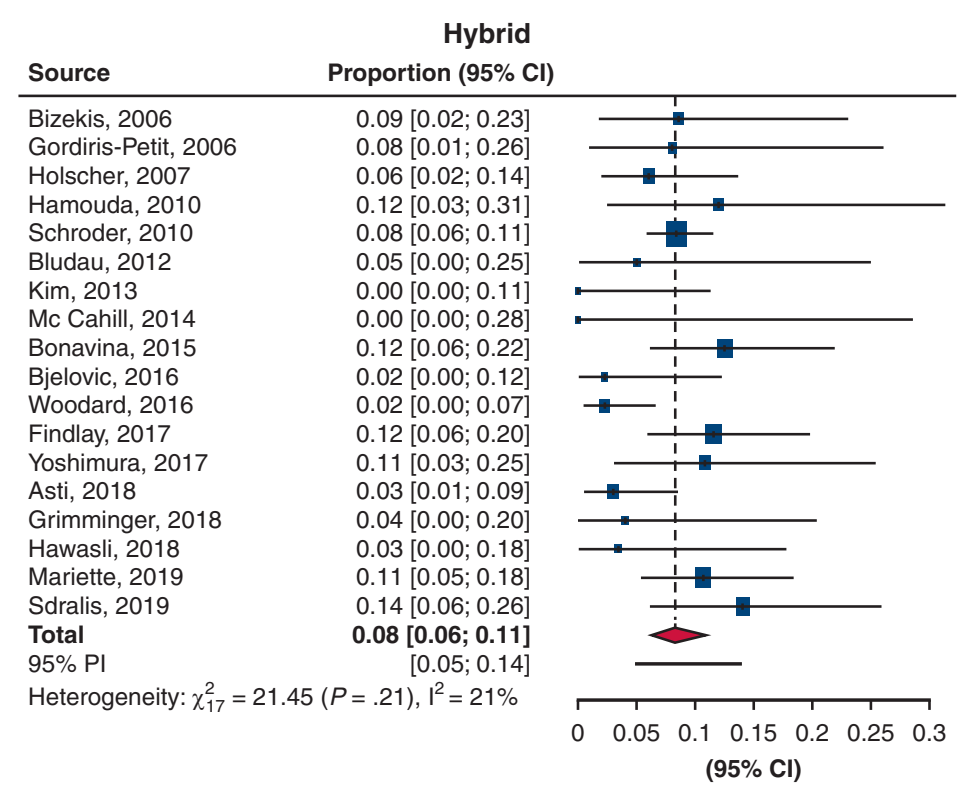

FIGURE 1. Continued.

HE, and $8 \%$ (95\% CI, 6\%-9\%) after TMIE. It was estimated that the risk of developing an anastomotic leak was significantly lower after $\mathrm{OE}$ (odds ratio [OR], 0.71; 95\% CI, 0.62-0.81; $P<.0001$ ), compared with TMIE. A similar risk of anastomotic leak was found among patients who underwent TMIE and HE (OR, 0.90; 95\% CI, 0.72-1.13; $P=.37$; Figure 1).

The overall morbidity rate was $45 \%(95 \%$ CI, $38 \%$ $52 \%)$ after $\mathrm{OE}, 40 \%(95 \% \mathrm{CI}, 25 \%-59 \%)$ after $\mathrm{HE}$, and $37 \%$ (95\% CI, 32\%-43\%) after TMIE. The risk of overall morbidity was higher after OE (OR, 1.37; 95\% CI, 1.26$1.49 ; P<.0001)$ compared with TMIE. The risk of overall morbidity was similar between TMIE and HE (OR, 1.13; 95\% CI, 0.94-1.37; $P=.19$; Figure 2).

The pneumonia rate was $14 \%(95 \%$ CI, $10 \%-20 \%)$, $13 \%$ (95\% CI, $8 \%-19 \%)$, and $9 \%(95 \% \mathrm{CI}, 8 \%-12 \%)$ after OE, HE, and TMIE, respectively. The risk of developing pneumonia was higher after OE (OR, 1.14; 95\% CI, 1-1.29; $P<.04)$, compared with TMIE. Rates of pneumonia were similar for patients who underwent TMIE and HE (OR, $0.85 ; 95 \%$ CI, $0.65-1.11 ; P=.24)$.

The arrhythmia rate was $8 \%$ (95\% CI, 6\%-12\%) after OE, $14 \%(95 \%$ CI, $8 \%-24 \%)$ after HE, and $11 \%(95 \%$ CI, $8 \%-15 \%$ ) after TMIE. The risk of developing arrhythmia was lower after OE (OR, 0.53; 95\% CI, 0.46$0.63 ; P<.0001)$, compared with TMIE. The arrhythmia rate was similar among patients who underwent TMIE and $\mathrm{HE}(\mathrm{OR}, 1 ; 95 \% \mathrm{CI}, 0.77-1.3 ; P=.97)$.

The pooled mortality rate was $4 \%$ (95\% CI, 3\%-4\%) after $\mathrm{OE}, 4 \%(95 \% \mathrm{CI}, 3 \%-6 \%)$ after $\mathrm{HE}$, and $2 \%(95 \% \mathrm{CI}$,
2\%-3\%) after TMIE. Risk estimation showed higher odds of mortality after $\mathrm{OE}(\mathrm{OR}, 2.22$; $95 \% \mathrm{CI}, 1.76 \%-2.81$; $P<.0001)$ and HE (OR, 1.93; 95\% CI, 1.32-2.81; $P<.001$ ) compared with TMIE (Figure 3 ).

Median LOS was 14.1 (range, 8-28), 12.5 (range, 8-18), and 11.9 (range, 7-30) days after OE, HE, and TMIE, respectively. Hospital stay was significantly shorter among patients who underwent TMIE $(P=.003)$. The main outcomes are summarized in Figure 4. Publication bias was detected for anastomotic leakage and mortality only in $\mathrm{OE}$ studies (Figure E2).

\section{DISCUSSION}

We aimed to compare postoperative outcomes for $\mathrm{OE}$, HE, and TMIE. Although OE was associated with shorter operative time and reduced anastomotic leakage rates, our study showed that minimally invasive surgery is associated with significantly lower rates of overall morbidity and mortality, along with shorter LOS. In addition, TMIE was associated with lower mortality and shorter LOS than HE.

Ivor Lewis esophagectomy is a complex procedure that is associated with high rates of perioperative

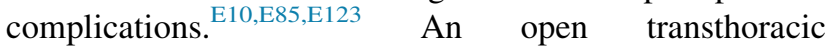
esophagectomy has shown overall postoperative adverse events rates as high as $73 \%$, with more than $30 \%$ of patients requiring reoperation or intensive care unit admission to treat complications. ${ }^{21}$ Minimally invasive surgery has been adopted by esophageal surgeons to decrease such morbidity rates. Previous studies have shown reduced 
Minimally invasive

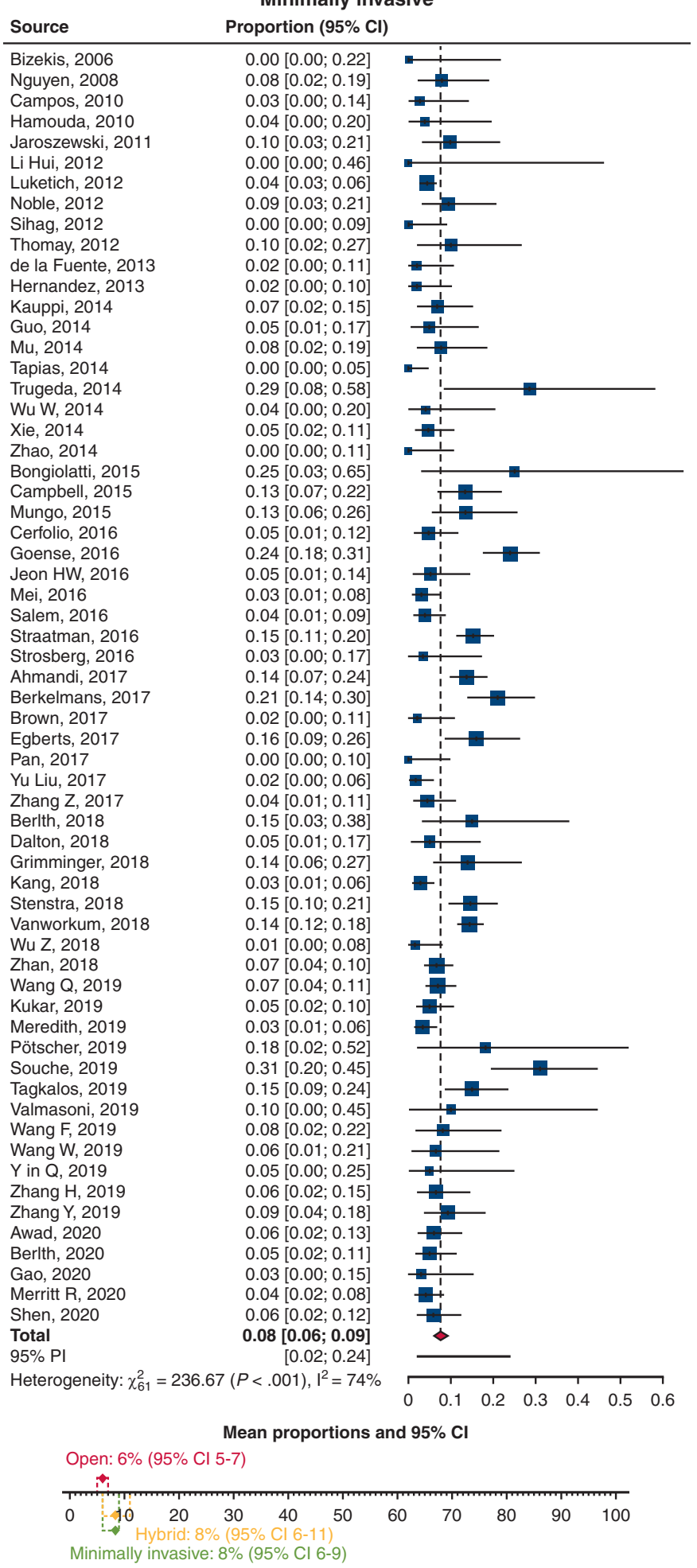

FIGURE 1. Continued. 


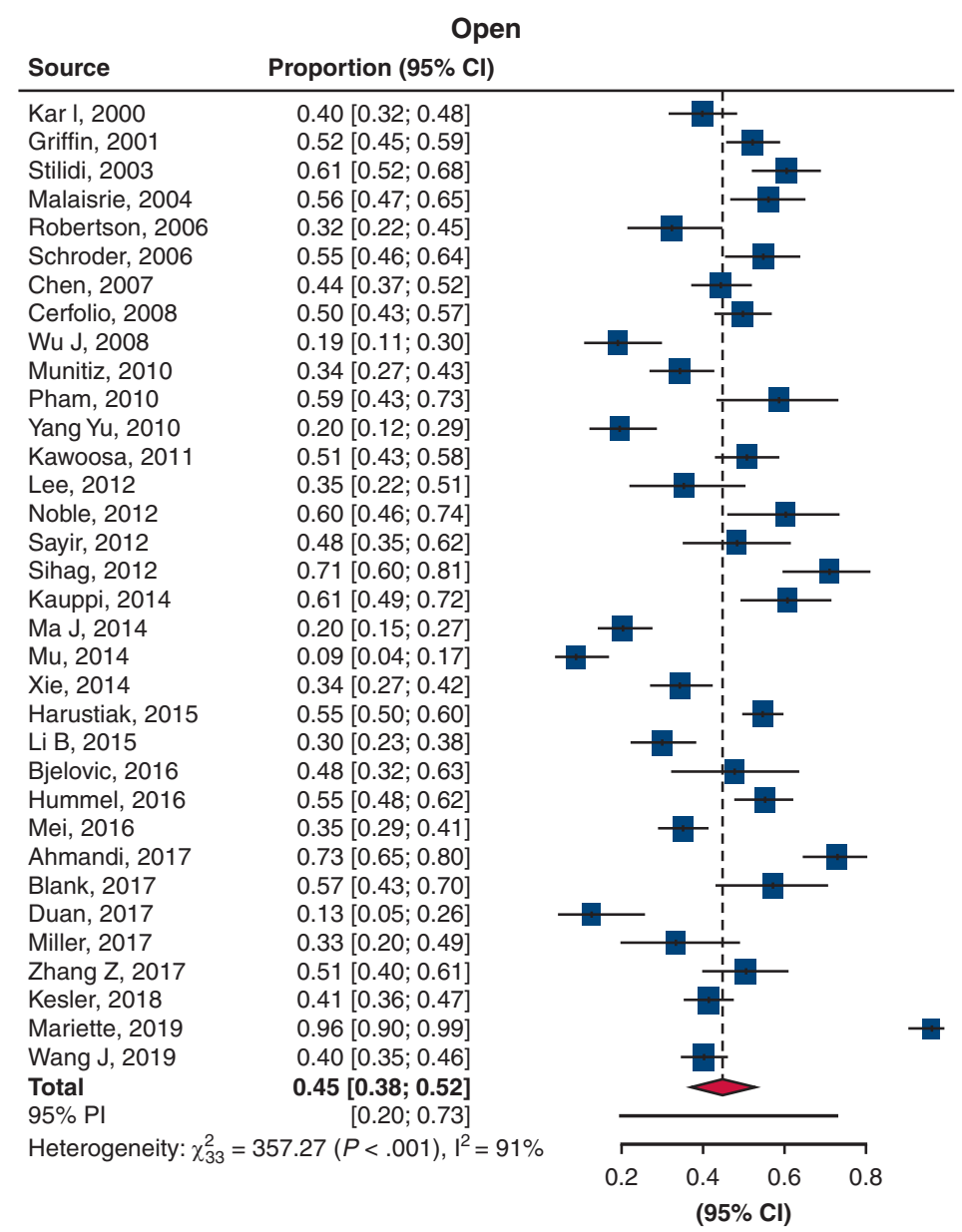

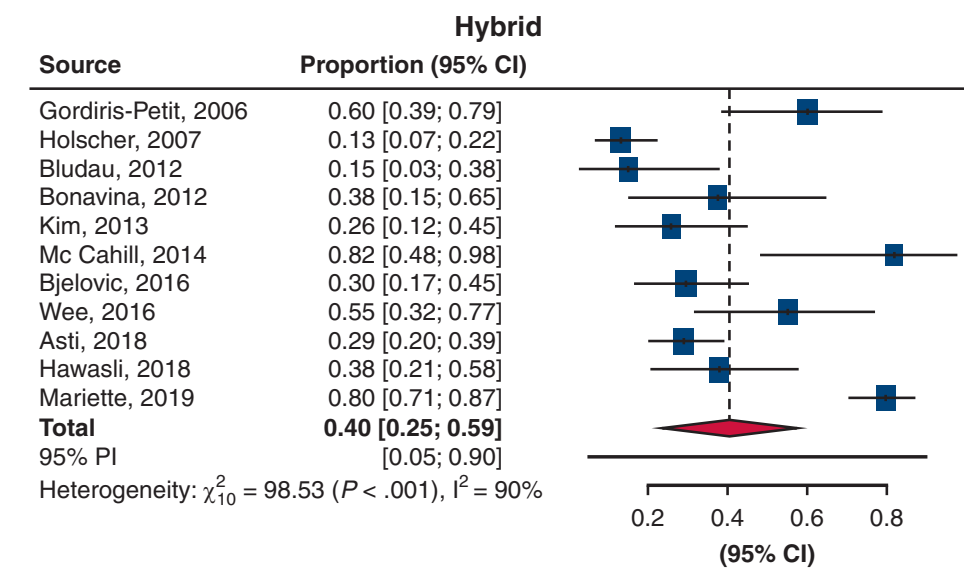

FIGURE 2. Proportion forest plots of overall morbidity in open, hybrid, and totally minimally invasive Ivor Lewis esophagectomy. $C I$, Confidence interval; $P I$, prediction interval.

amounts of intraoperative blood loss, lower rates of pulmonary infection, faster resumption of bowel function, and shorter hospital stay with the use of minimally invasive surgery. ${ }^{\mathrm{E} 37, \mathrm{E} 124-\mathrm{E} 127}$ In line with these findings, our pooled analysis of a large cohort of patients exposed that patients undergoing $\mathrm{OE}$ have higher risks of overall morbidity and mortality, as compared to those undergoing TMIE. The incidence of postoperative pneumonia, specifically, was 


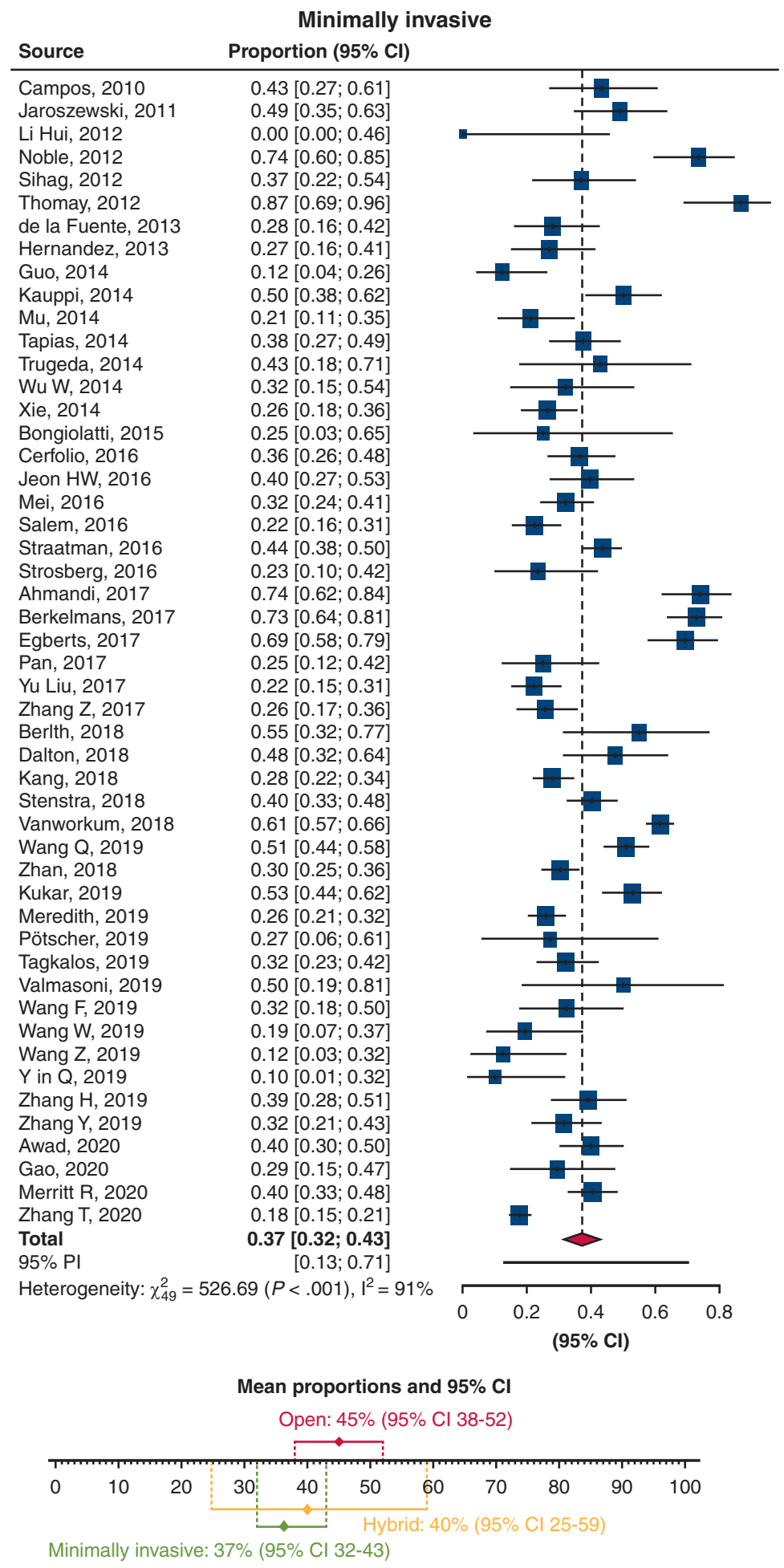

FIGURE 2. Continued.

also notably higher after OE. In addition, we also found that open esophagectomies were associated with longer LOS.

HE can be considered as an initial step toward performing TMIE. ${ }^{\text {E62 }}$ Several studies have compared outcomes

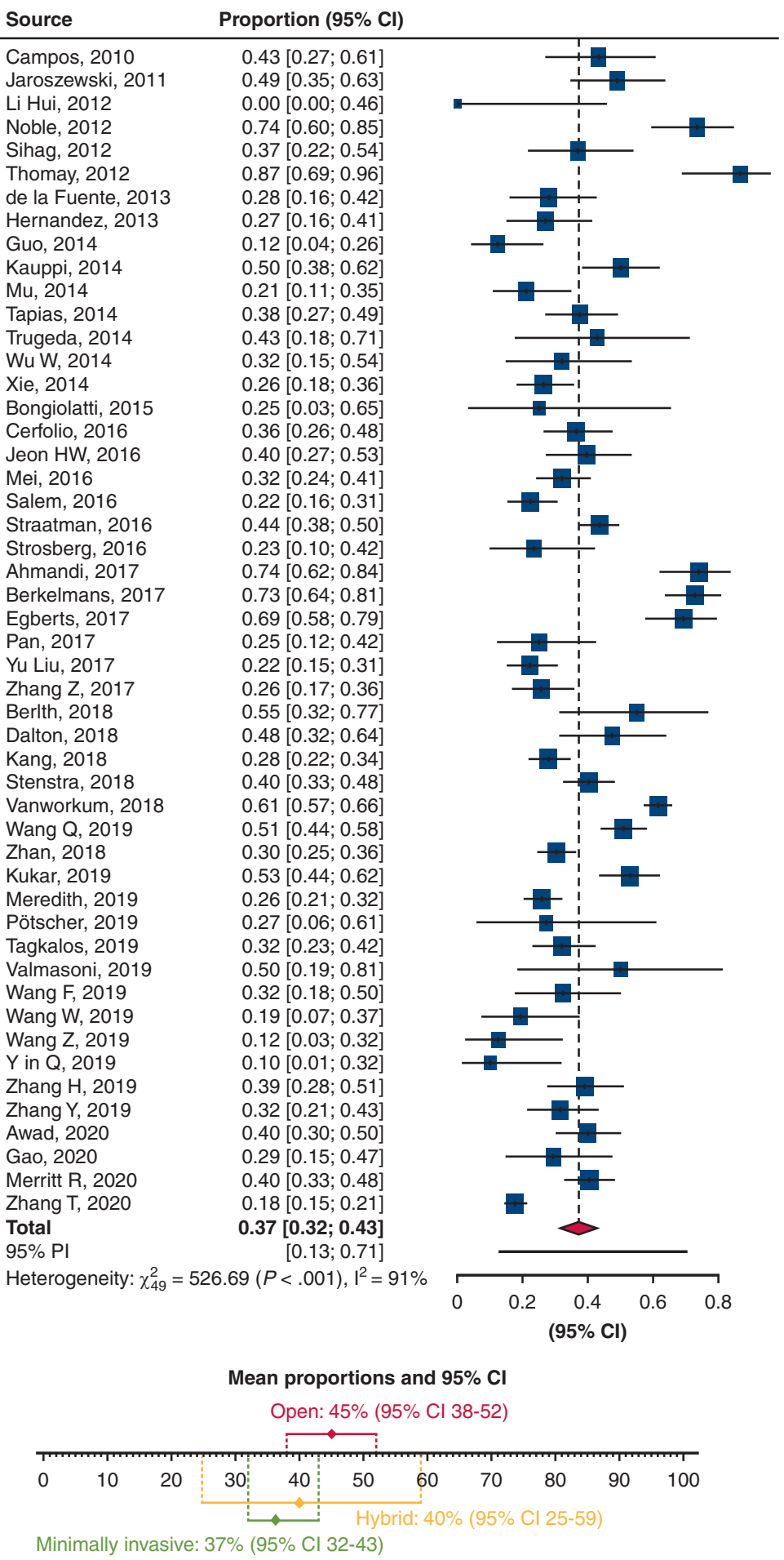

FGURE 2. Continued. 


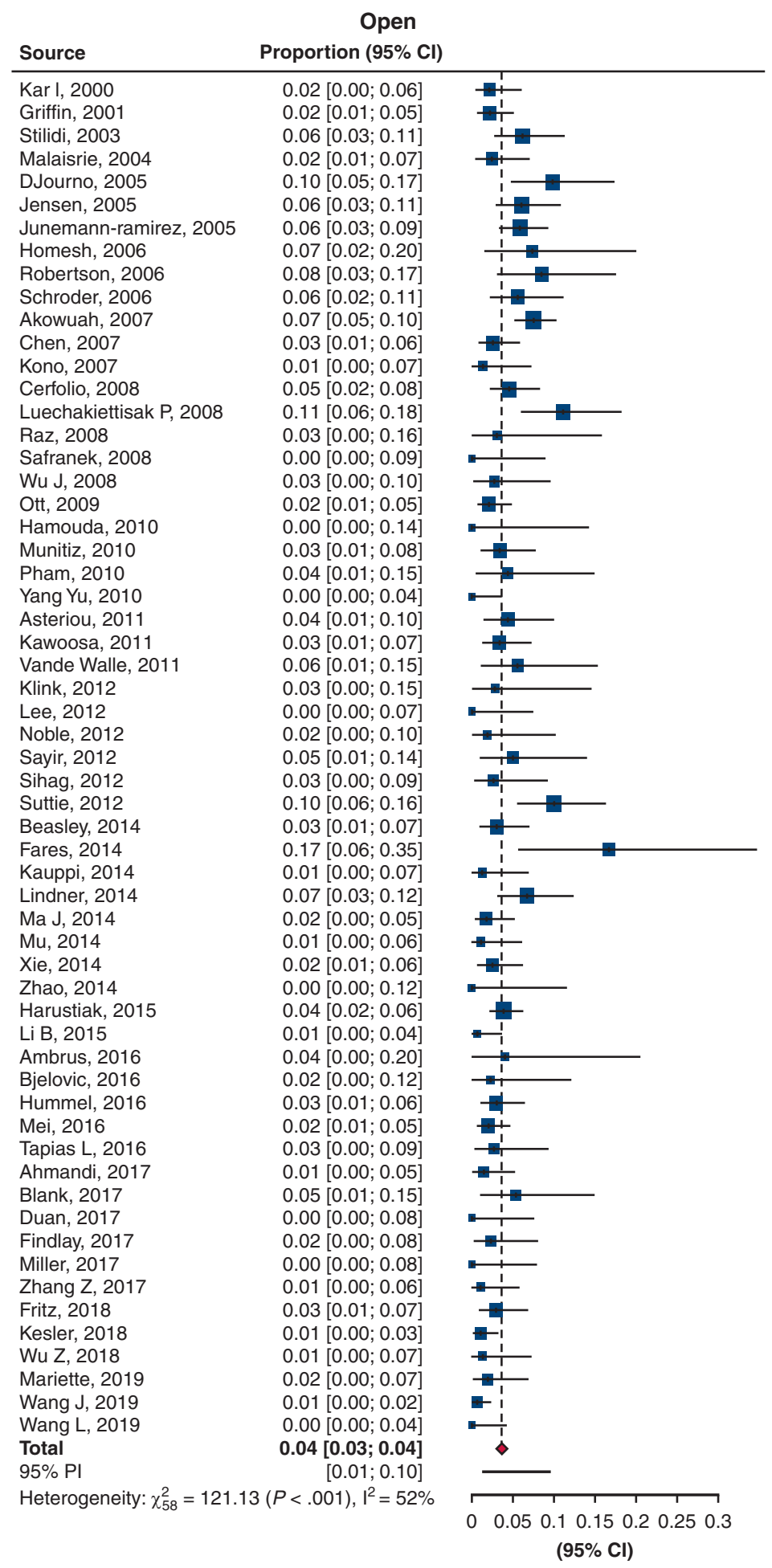

FIGURE 3. Proportion forest plots of mortality in open, hybrid, and totally minimally invasive Ivor Lewis esophagectomy. $C I$, Confidence interval; PI, prediction interval.

Similarly, the MIRO clinical trial compared HE (laparoscopic gastric mobilization with open right thoracotomy) with $\mathrm{OE}$, and also showed higher rates of pulmonary and major postoperative complications in patients who underwent OE. ${ }^{19}$ However, few studies have compared outcomes for HE and TMIE. ${ }^{\text {E61,E74,E130 }}$ Grimminger and 

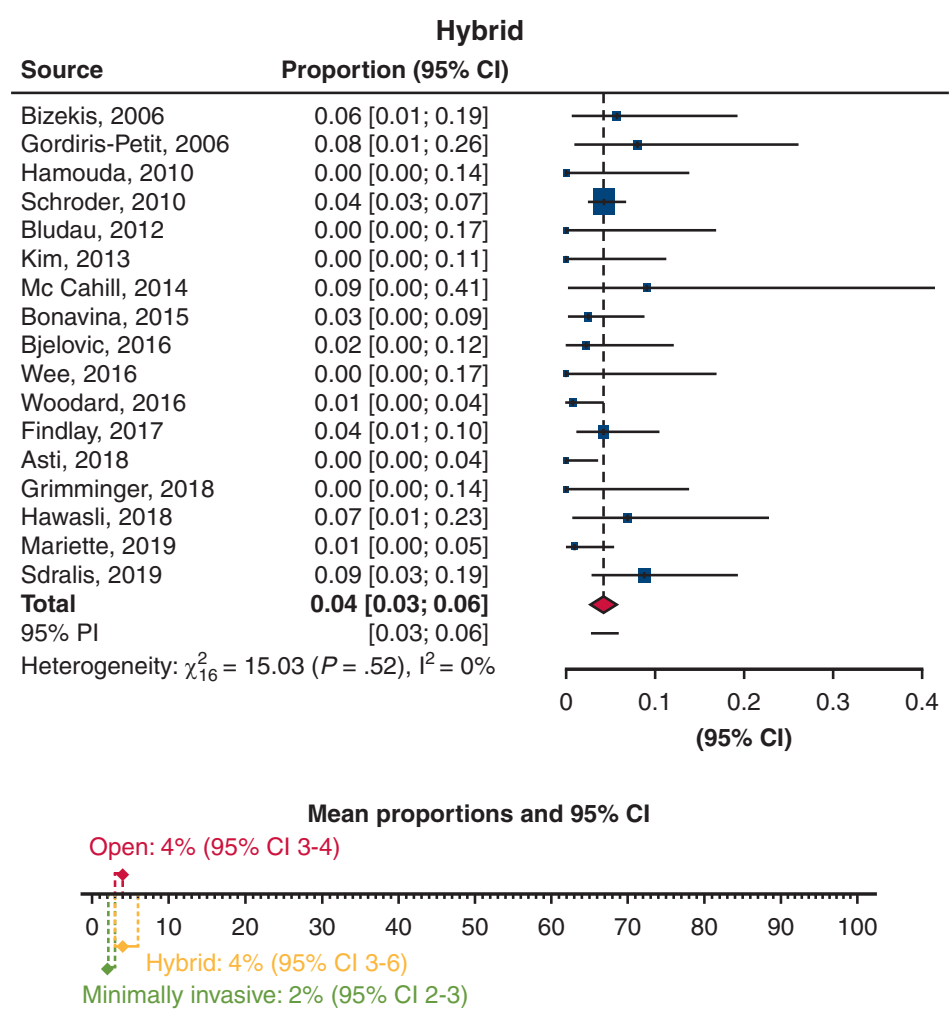

FIGURE 3. Continued.

colleagues ${ }^{\mathrm{E} 74}$ compared perioperative results for HE and TMIE, and reported similar LOS and mortality rates between groups. However, pneumonia and wound infections occurred more often in the hybrid group. ${ }^{\text {E74 }}$ Another study showed that TMIE had a small benefit in terms of blood loss and LOS but similar rates of postoperative complications, compared with HE. ${ }^{\mathrm{E} 130}$ Interestingly, many studies on surgical outcomes after esophagectomy have included HE in the minimally invasive surgery group (without discrimination between HE and TMIE). ${ }^{\text {E131-E134 }}$ A critical finding of our study was that patients undergoing $\mathrm{HE}$ had considerably higher rates of postoperative mortality and longer LOS than those undergoing TMIE. Therefore, additional efforts are needed to continue embracing a totally minimally invasive approach.

Anastomotic leak is one of the most serious complications after esophagectomy, especially for patients with an intrathoracic anastomosis. Our analysis showed that $\mathrm{OE}$ had lower rates of anastomotic leak compared with TMIE and HE. Remarkably, other studies have also shown lower anastomotic leakage rates with the open approach. ${ }^{15, \text { E135 }}$ For example, Seesing and colleagues ${ }^{15}$ performed a propensity score-matched analysis of patients who underwent $\mathrm{OE}$ $(\mathrm{n}=433)$ and minimally invasive Ivor Lewis esophagectomy $(\mathrm{n}=433)$, and reported higher leakage rates in the minimally invasive group $(15.5 \%$ vs $21.2 \% ; P=.028)$ We hypothesize that these findings are partially explained by the steep learning curve of TMIE. ${ }^{\text {135-E137 }}$ For instance, Fumagalli and colleagues ${ }^{\mathrm{E} 138}$ reported that the mean incidence of anastomotic leakage during the learning curve of TMIE was $18.8 \%$, but it was only $4.5 \%$ after the plateau had been reached. In addition, we found that operative time was shorter for $\mathrm{OE}$, and this result could also be influenced by the learning curve of TMIE. In fact, a previous study reported no differences in the operative time between TMIE and OE when performed by experienced surgeons. $^{\text {E139 }}$

This study has several limitations. Mainly, most studies included for analysis were retrospective, potentially affected by selection and reporting bias. Furthermore, notable publication bias was detected in OE studies. In addition, important heterogeneity in defining and measuring outcomes was identified among the included studies. Finally, surgical volume (which affects postoperative outcomes after an esophagectomy) was not evaluated. However, the main strength of our study is that we compared outcomes for the 3 different approaches only in patients with intrathoracic anastomosis. The main findings of our study are described in Figure 5 and in a video form related by the first author of the paper (Video 1). 
Minimally invasive

Source

Proportion $(95 \% \mathrm{Cl})$

Bizekis, 2006

Nguyen, 2008

Hamouda, 2010

Jaroszewski, 2011

Li Hui, 2012

Luketich, 2012

Noble, 2012

Sihag, 2012

Thomay, 2012

de la Fuente, 2013

Hernandez, 2013

Guo, 2014

Kauppi, 2014

$\mathrm{Mu}, 2014$

Tapias, 2014

Trugeda, 2014

Wu W, 2014

Xie, 2014

Zhao, 2014

Campbell, 2015

Bongiolatti, 2015

Mungo, 2015

Cerfolio, 2016

Jeon HW, 2016

Mei, 2016

Salem, 2016

Straatman, 2016

Strosberg, 2016

Ahmandi, 2017

Berkelmans, 2017

Brown, 2017

Egberts, 2017

Pan, 2017

Yu Liu, 2017

Zhang Z, 2017

Berlth, 2018

Dalton, 2018

Grimminger, 2018

Kang, 2018

Stenstra, 2018

Vanworkum, 2018

Wu Z, 2018

Zhan, 2018

Wang Q, 2019

Kukar, 2019

Meredith, 2019

Souche, 2019

Tagkalos, 2019

Valmasoni, 2019

Wang F, 2019

Wang W, 2019

Wang Z, 2019

$Y$ in Q, 2019

Zhang H, 2019

Zhang Y, 2019

Awad, 2020

Berlth, 2020

Gao, 2020

Merritt R, 2020

Zhang T, 2020

Total

0.07 [0.00; 0.32$]$

$0.02[0.00 ; 0.10]$

$0.00[0.00 ; 0.13]$

$0.06[0.01 ; 0.16]$

$0.00[0.00 ; 0.46]$

$0.01[0.00 ; 0.02]$

0.02 [0.00; 0.10 ]

0.00 [0.00; 0.09 ]

$0.00[0.00 ; 0.12]$

0.00 [0.00; 0.07$]$

$0.00[0.00 ; 0.07]$

$0.00[0.00 ; 0.09]$

0.03 [0.00; 0.09 ]

0.02 [0.00; 0.09 ]

$0.00[0.00 ; 0.05]$

0.00 [0.00; 0.23 ]

$0.00[0.00 ; 0.14]$

0.02 [0.00; 0.07$]$

$0.00[0.00 ; 0.11]$

$0.00[0.00 ; 0.04]$

$0.00[0.00 ; 0.37]$

$0.04[0.00 ; 0.13]$

$0.04[0.01 ; 0.10]$

$0.02[0.00 ; 0.09]$

0.02 [0.00; 0.07 ]

$0.02[0.00 ; 0.05]$

$0.02[0.01 ; 0.05$

0.03 [0.00; 0.17

$0.05[0.02 ; 0.13]$

$0.01[0.00 ; 0.05]$

$0.06[0.01 ; 0.17]$

$0.04[0.01 ; 0.11]$

$0.00[0.00 ; 0.10]$

$0.00[0.00 ; 0.03]$

$0.01[0.00 ; 0.06]$

0.05 [0.00; 0.25$]$

$0.03[0.00 ; 0.13]$

$0.00[0.00 ; 0.07]$

$0.00[0.00 ; 0.03]$

$0.04[0.01 ; 0.08]$

$0.02[0.01 ; 0.04]$

$0.01[0.00 ; 0.08]$

$0.00[0.00 ; 0.02]$

$0.02[0.01 ; 0.05]$

$0.02[0.01 ; 0.07]$

$0.02[0.00 ; 0.04]$

$0.00[0.00 ; 0.06]$

$0.03[0.01 ; 0.09]$

$0.00[0.00 ; 0.31]$

$0.00[0.00 ; 0.09]$

$0.00[0.00 ; 0.11]$

$0.00[0.00 ; 0.14]$

$0.00[0.00 ; 0.17]$

$0.00[0.00 ; 0.05]$

$0.01[0.00 ; 0.07]$

$0.03[0.01 ; 0.09]$

$0.01[0.00 ; 0.05]$

$0.00[0.00 ; 0.10]$

$0.01[0.00 ; 0.04]$

$0.01[0.01 ; 0.03]$

$0.02[0.02 ; 0.03]$

$[0.02 ; 0.03]$

Heterogeneity: $\chi_{59}^{2}=39.41(P=.98), \mathrm{I}^{2}=0 \%$
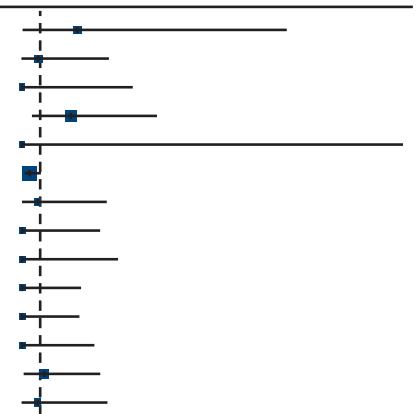

$+1$
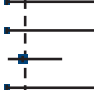

$\frac{1}{1}$
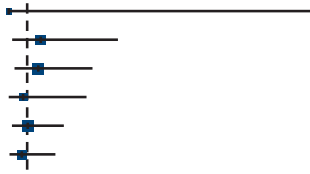

담
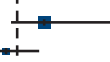

$\stackrel{1}{1}$

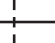

T
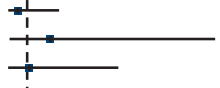

$-1$
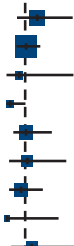

$-\frac{1}{1+2}$
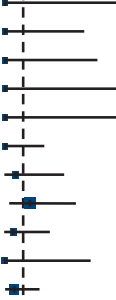

$\checkmark$

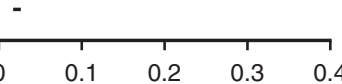

$(95 \% \mathrm{Cl})$

FIGURE 3. Continued. 


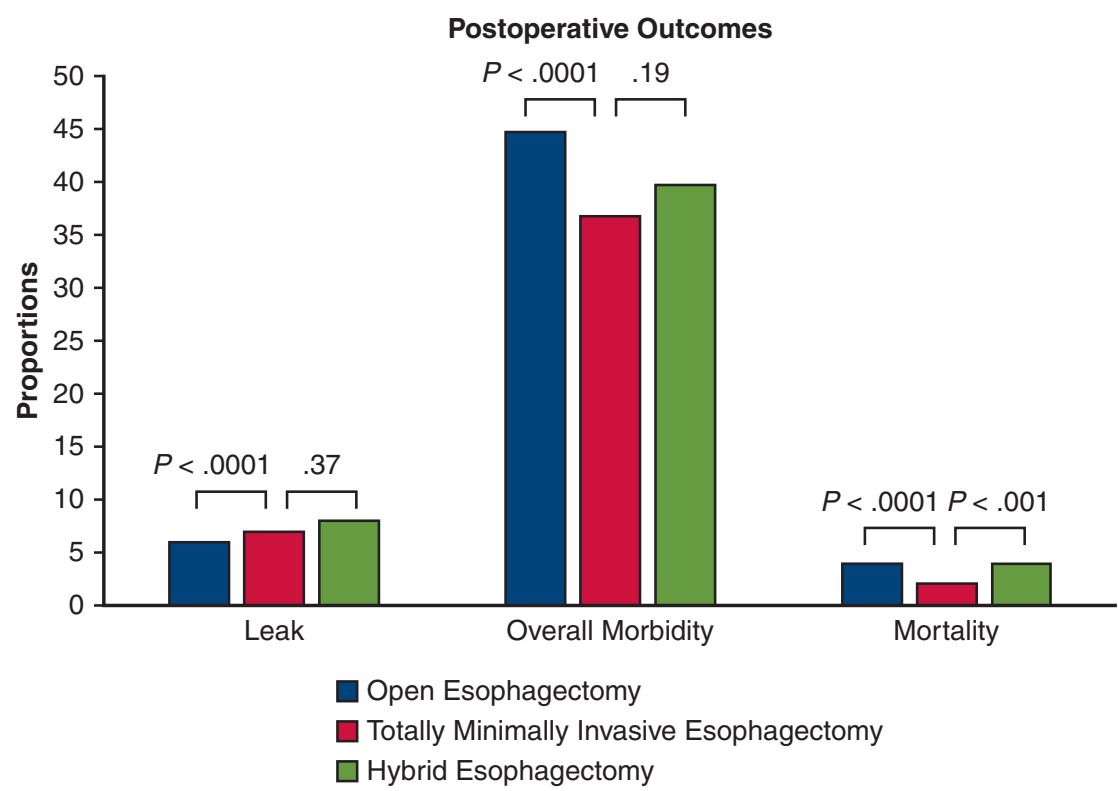

FIGURE 4. Comparison of surgical outcomes of open, hybrid, and totally minimally invasive Ivor Lewis esophagectomy.

\section{CONCLUSIONS}

Although OE was associated with shorter operative time and reduced anastomotic leakage rates, our study showed that HE and TMIE are associated with lower rates of overall morbidity, reduced postoperative mortality, and shorter LOS. In addition, TMIE was associated with lower mortality rates and shorter LOS than HE. Further efforts are needed to widely embrace TMIE in a safe manner.

\section{Conflict of Interest Statement}

The authors reported no conflicts of interest.

\section{Perioperative results after Open vs hybrid vs totally minimally invasive Ivor-Lewis esophagectomy}

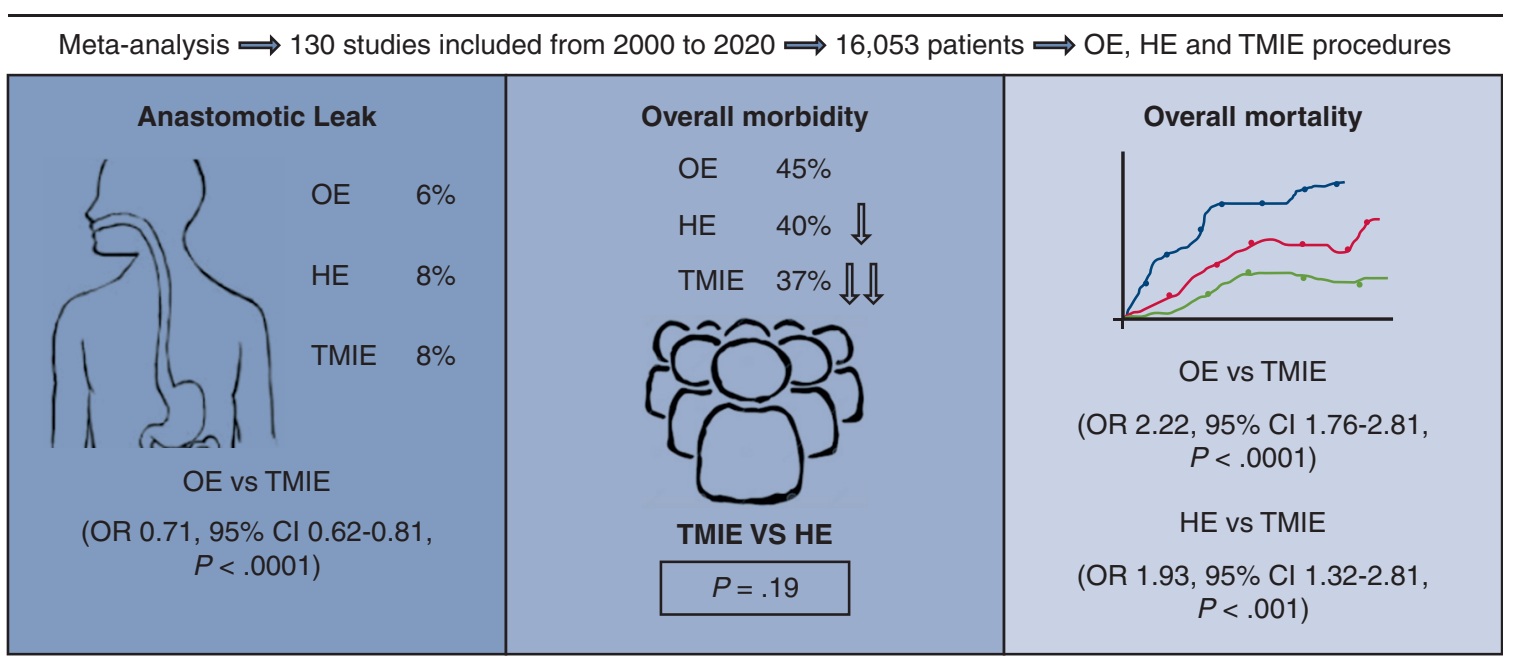

TMIE was associated with lower rates of overall morbidity, postoperative mortality, and shorter hospital stay, as compared to OE. Also, it was associated with lower mortality and shorter hospital stay than HE. Further efforts are needed to embrace this approach in a safely manner

*OE: Open Ivor lewis esophagectomy, HE: Hybrid Ivor lewis esophagectomy, TMIE: Totally minimally invasive ivor lewis esophagectomy.

FIGURE 5. Main findings of the study. $O E$, Open esophagectomy; $H E$, hybrid esophagectomy; TMIE, totally minimally invasive esophagectomy. 


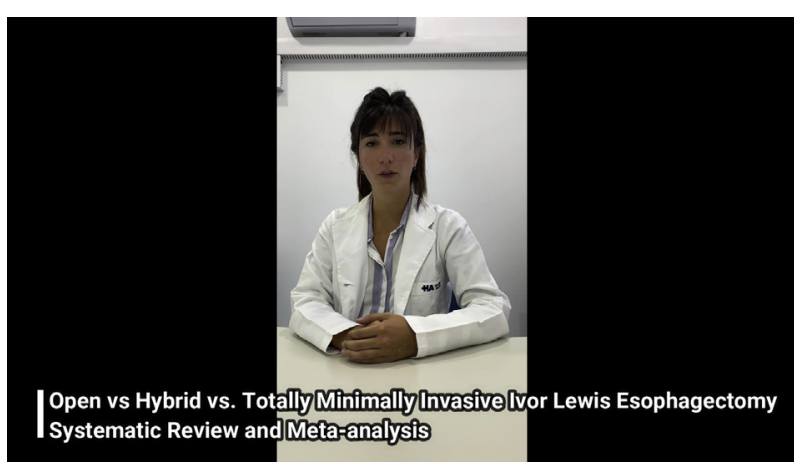

VIDEO 1. The first author of the study describes the most relevant findings of the meta-analysis. Video available at: https://www.jtcvs.org/ article/S0022-5223(22)00031-9/fulltext.

The Journal policy requires editors and reviewers to disclose conflicts of interest and to decline handling or reviewing manuscripts for which they may have a conflict of interest. The editors and reviewers of this article have no conflicts of interest.

\section{References}

1. Global Burden of Disease Cancer Collaboration. Global, regional, and national cancer incidence, mortality, years of life lost, years lived with disability, and disability-adjusted life-years for 32 cancer groups, 1990 to 2015: a systematic analysis for the Global Burden of Disease Study. JAMA Oncol. 2017:3:524-48.

2. GBD 2017 Oesophageal Cancer Collaborators. The global, regional, and national burden of oesophageal cancer and its attributable risk factors in 195 countries and territories, 1990-2017: a systematic analysis for the Global Burden of Disease Study 2017. Lancet Gastroenterol Hepatol. 2020;5: 582-97.

3. Bray F, Ferlay J, Soerjomataram I, Siegel RL, Torre LA, Jemal A. Global cancer statistics 2018: GLOBOCAN estimates of incidence and mortality worldwide for 36 cancers in 185 countries. CA Cancer J Clin. 2018;68:394-424.

4. Umar S, Fleischer D. Esophageal cancer: epidemiology, pathogenesis and prevention. Nat Rev Gastroenterol Hepatol. 2008;5:517-26.

5. Ilson DH, van Hillegersberg R. Management of patients with adenocarcinoma or squamous cancer of the esophagus. Gastroenterology. 2018;154:437-51.

6. Law S, Wong J. What is appropriate treatment for carcinoma of the thoracic esophagus? World J Surg. 2001;25:189-95.

7. Lewis I. The surgical treatment of carcinoma of the oesophagus; with special reference to a new operation for growths of the middle third. Br J Surg. 1946; 34:18-31.

8. Cuschieri A, Shimi S, Banting S. Endoscopic oesophagectomy through a right thoracoscopic approach. J R Coll Surg Edinb. 1992;37:7-11.

9. Tapias LF, Morse CR. A preliminary experience with minimally invasive Ivor Lewis esophagectomy. Dis Esophagus. 2011;25:449-55.
10. Zhang Z, Xu M, Guo M, Liu X. Long-term outcomes of minimally invasive Ivor Lewis esophagostomy for esophageal squamous cell carcinoma: compared with open approach. Int J Surg. 2017;45:98-104.

11. Mann C, Berlth F, Hadzijusufovic E, Lang H, Grimminger PP. Minimally invasive esophagectomy: clinical evidence and surgical techniques. Langenbecks Arch Surg. 2020;405:1061-7.

12. Meredith KL, Maramara T, Blinn P, Lee D, Huston J, Shridhar R. Comparative perioperative outcomes by esophagectomy surgical technique. J Gastrointest Surg. 2020;24:1261-8.

13. Naffouje SA, Salloum RH, Khalaf Z, Salti GI. Outcomes of open versus minimally invasive Ivor-Lewis esophagectomy for cancer: a propensity-score matched analysis of NSQIP database. Ann Surg Oncol. 2019;26:2001-10.

14. Luketich JD, Pennathur A, Franchetti Y, Catalano PJ, Swanson S, Sugarbaker DJ, et al. Minimally invasive esophagectomy: results of a prospective phase II multicenter trial-the Eastern Cooperative Oncology Group (E2202) study. Ann Surg. 2015;261:702-7.

15. Seesing MFJ, Gisbertz SS, Goense L, van Hillegersberg R, Kroon HM, Lagarde SM, et al. A propensity score matched analysis of open versus minimally invasive transthoracic esophagectomy in the Netherlands. Ann Surg. 2017;266: 839-46.

16. Briez N, Piessen G, Torres F, Lebuffe G, Triboulet JP, Mariette C. Effects of hybrid minimally invasive oesophagectomy on major postoperative pulmonary complications. Br J Surg. 2012;99:1547-53.

17. Mariette C, Markar SR, Dabakuyo-Yonli TS, Meunier B, Pezet D, Collet D, et al. Hybrid minimally invasive esophagectomy for esophageal cancer. $N$ Engl J Med. 2019;380:152-62.

18. Voron T, Lintis A, Piessen G. Hybrid esophagectomy. J Thorac Dis. 2019; 11(Suppl 5):S723-7.

19. Nuytens F, Dabakuyo-Yonli TS, Meunier B, Gagnière J, Collet D, D'Journo XB, et al. Five-year survival outcomes of hybrid minimally invasive esophagectomy in esophageal cancer: results of the MIRO randomized clinical trial. JAMA Surg. 2021;156:323-32.

20. van Workum F, Klarenbeek BR, Baranov N, Rovers MM, Rosman C. Totally minimally invasive esophagectomy versus hybrid minimally invasive esophagectomy: systematic review and meta-analysis. Dis Esophagus. 2020;33: doaa021.

21. Ahmadi N, Crnic A, Seely AJ, Sundaresan SR, Villeneuve PJ, Maziak DE, et al. Impact of surgical approach on perioperative and long-term outcomes following esophagectomy for esophageal cancer. Surg Endosc. 2018;32:1892-900.

22. Asteriou C, Barbetakis N, Lalountas M, Kleontas A, Tsilikas C. Modified pleural tenting for prevention of anastomotic leak after Ivor Lewis esophagogastrectomy. Ann Surg Oncol. 2011;18:3737-42.

23. Beasley WD, Jefferies MT, Gilmour J, Manson JM. A single surgeon's series of transthoracic oesophageal resections. Ann R Coll Surg Engl. 2014;96:151-6.

24. Bonavina L, Scolari F, Aiolfi A, Bonitta G, Sironi A, Saino G, et al. Early outcome of thoracoscopic and hybrid esophagectomy: propensity-matched comparative analysis. Surgery. 2016;159:1073-81.

25. Brinkmann S, Chang DH, Kuhr K, Hoelscher AH, Spiro J, Bruns CJ, et al. Stenosis of the celiac trunk is associated with anastomotic leak after Ivor-Lewis esophagectomy. Dis Esophagus. 2019;32:doy 107.

Key Words: Ivor Lewis esophagectomy, transthoracic esophagectomy, open esophagectomy, hybrid esophagectomy, minimally invasive esophagectomy 


\section{E References}

E1. Brown AM, Pucci MJ, Berger AC, Tatarian T, Evans NR, Rosato EL, et al. A standardized comparison of peri-operative complications after minimally invasive esophagectomy: Ivor Lewis versus McKeown. Surg Endosc. 2017; 32:204-11.

E2. Campbell C, Reames MK, Robinson M, Symanowski J, Salo JC. Conduit vascular evaluation is associated with reduction in anastomotic leak after esophagectomy. J Gastrointest Surg. 2015;19:806-12.

E3. Campos GM, Jablons D, Brown LM, Ramirez RM, Rabl C, Theodore P. A safe and reproducible anastomotic technique for minimally invasive Ivor Lewis oesophagectomy: the circular-stapled anastomosis with the trans-oral anvil. Eur J Cardiothorac Surg. 2010;37:1421-6.

E4. Cerfolio RJ, Wei B, Hawn MT, Minnich DJ. Robotic esophagectomy for cancer: early results and lessons learned. Semin Thorac Cardiovasc Surg. 2016; 28:160-9.

E5. Dalton BGA, Ali AA, Crandall M, Awad ZT. Near infrared perfusion assessment of gastric conduit during minimally invasive Ivor Lewis esophagectomy. Am J Surg. 2018;216:524-7.

E6. de la Fuente SG, Weber J, Hoffe SE, Shridhar R, Karl R, Meredith KL. Initial experience from a large referral center with robotic-assisted Ivor Lewis esophagogastrectomy for oncologic purposes. Surg Endosc. 2013;27:3339-47.

E7. Deldycke A, Van Daele E, Ceelen W, Van Nieuwenhove Y, Pattyn P. Functional outcome after Ivor Lewis esophagectomy for cancer. J Surg Oncol. 2015;113:24-8.

E8. Goense L, van Rossum PSN, Weijs TJ, van Det MJ, Nieuwenhuijzen GA, Luyer MD, et al. Aortic calcification increases the risk of anastomotic leakage after Ivor-Lewis esophagectomy. Ann Thorac Surg. 2016;102: 247-52.

E9. Godiris-Petit G, Munoz-Bongrand N, Honigman I, Cattan P, Sarfati E. Minimally invasive esophagectomy for cancer: prospective evaluation of laparoscopic gastric mobilization. World J Surg. 2006;30:1434-40.

E10. Griffin SM, Shaw IH, Dresner SM. Early complications after Ivor Lewis subtotal esophagectomy with two-field lymphadenectomy: risk factors and management. J Am Coll Surg. 2002;194:285-97.

E11. Guo W, Ma L, Zhang Y, Ma X, Yang S, Zhu X, et al. Totally minimally invasive Ivor-Lewis esophagectomy with single-utility incision video-assisted thoracoscopic surgery for treatment of mid-lower esophageal cancer. Dis Esophagus. 2016;29:139-45.

E12. Harustiak T, Pazdro A, Snajdauf M, Stolz A, Lischke R. Anastomotic leak and stricture after hand-sewn versus linear-stapled intrathoracic oesophagogastric anastomosis: single-centre analysis of 415 oesophagectomies. Eur J Cardiothorac Surg. 2016;49:1650-9.

E13. Hölscher AH, Schneider PM, Gutschow C, Schröder W. Laparoscopic ischemic conditioning of the stomach for esophageal replacement. Ann Surg. 2007; 245:241-6.

E14. Jaroszewski DE, Williams DG, Fleischer DE, Ross HJ, Romero Y, Harold KL. An early experience using the technique of transoral OrVil EEA stapler for minimally invasive transthoracic esophagectomy. Ann Thorac Surg. 2011; 92:1862-9.

E15. Junemann-Ramirez M, Awan MY, Khan ZM, Rahamim JS. Anastomotic leakage post-esophagogastrectomy for esophageal carcinoma: retrospective analysis of predictive factors, management and influence on longterm survival in a high volume centre. Eur J Cardiothorac Surg. 2005;27:3-7.

E16. Kang N, Zhang R, Ge W, Si P, Jiang M, Huang Y, et al. Major complications of minimally invasive Ivor Lewis oesophagectomy using the purse string-stapled anastomotic technique in 215 patients with oesophageal carcinoma. Interact Cardiovasc Thorac Surg. 2018;27:708-13.

E17. Karl RC, Schreiber R, Boulware D, Baker S, Coppola D. Factors affecting morbidity, mortality, and survival in patients undergoing Ivor Lewis esophagogastrectomy. Ann Surg. 2000;231:635-43.

E18. Kesler KA, Ramchandani NK, Jalal SI, Stokes SM, Mankins MR, Ceppa D, et al. Outcomes of a novel intrathoracic esophagogastric anastomotic technique. J Thorac Cardiovasc Surg. 2018;156:1739-17345.e1.

E19. Kim K, Park JS, Seo H. Early outcomes of video-assisted thoracic surgery (VATS) Ivor Lewis operation for esophageal squamous cell carcinoma: the extracorporeal anastomosis technique. Surg Laparosc Endosc Percutan Tech. 2013;23:303-8.

E20. Klink CD, Binnebösel M, Otto J, Boehm G, von Trotha KT, Hilgers RD, et al. Intrathoracic versus cervical anastomosis after resection of esophageal cancer: a matched pair analysis of 72 patients in a single center study. World J Surg Oncol. 2012;10:159.
E21. Kono K, Sugai H, Omata H, Fujii H. Transient bloodletting of the short gastric vein in the reconstructed gastric tube improves gastric microcirculation during esophagectomy. World J Surg. 2007;31:780-4; discussion: 785-6.

E22. Luechakiettisak P, Kasetsunthorn S. Comparison of hand-sewn and stapled in esophagogastric anastomosis after esophageal cancer resection: a prospective randomized study. J Med Assoc Thai. 2008;91:681-5.

E23. Miller DL, Helms GA, Mayfield WR. Evaluation of esophageal anastomotic integrity with serial pleural amylase levels. Ann Thorac Surg. 2018;105:200-6.

E24. Munitiz V, Martinez-de-Haro LF, Ortiz A, Ruiz-de-Angulo D, Pastor P, Parrilla P. Effectiveness of a written clinical pathway for enhanced recovery after transthoracic (Ivor Lewis) oesophagectomy. Br J Surg. 2010;97:714-8.

E25. Nguyen NT, Hinojosa MW, Smith BR, Chang KJ, Gray J, Hoyt D. Minimally invasive esophagectomy: lessons learned from 104 operations. Ann Surg. 2008;248:1081-91.

E26. Noble F, Kelly JJ, Bailey IS, Byrne JP, Underwood TJ. South Coast Cancer Collaboration-Oesophago-Gastric (SC3-OG). A prospective comparison of totally minimally invasive versus open Ivor Lewis esophagectomy. Dis Esophagus. 2013;26:263-71.

E27. Ott K, Bader FG, Lordick F, Feith M, Bartels H, Siewert JR. Surgical factors influence the outcome after Ivor-Lewis esophagectomy with intrathoracic anastomosis for adenocarcinoma of the esophagogastric junction: a consecutive series of 240 patients at an experienced center. Ann Surg Oncol. 2009;16: 1017-25.

E28. Raz DJ, Tedesco P, Herbella FA, Nipomnick I, Way LW, Patti MG. Side-toside stapled intra-thoracic esophagogastric anastomosis reduces the incidence of leaks and stenosis. Dis Esophagus. 2008;21:69-72.

E29. Robertson SA, Skipworth RJ, Clarke DL, Crofts TJ, Lee A, de Beaux AC, et al. Ventilatory and intensive care requirements following oesophageal resection. Ann R Coll Surg Engl. 2006;88:354-7.

E30. Safranek PM, Sujendran V, Baron R, Warner N, Blesing C, Maynard ND. Oxford experience with neoadjuvant chemotherapy and surgical resection for esophageal adenocarcinomas and squamous cell tumors. Dis Esophagus. 2008;21:201-6.

E31. Salem AI, Thau MR, Strom TJ, Abbott AM, Saeed N, Almhanna K, et al. Effect of body mass index on operative outcome after robotic-assisted IvorLewis esophagectomy: retrospective analysis of 129 cases at a single highvolume tertiary care center. Dis Esophagus. 2017;30:1-7.

E32. Sayir F, Cobanoğlu U, Sehitoğulları A. The use of LigaSure vessel sealing system in Ivor Lewis esophagectomy. J Cardiothorac Surg. 2012;7:10.

E33. Schröder W, Hölscher AH, Bludau M, Vallböhmer D, Bollschweiler E, Gutschow C. Ivor-Lewis esophagectomy with and without laparoscopic conditioning of the gastric conduit. World J Surg. 2010;34:738-43.

E34. Sdralis E, Tzaferai A, Davakis S, Syllaios A, Kordzadeh A, Lorenzi B, et al. Reinforcement of intrathoracic oesophago-gastric anastomosis with fibrin sealant (Tisseel $\left.{ }^{\circledR}\right)$ in oesophagectomy for cancer: a prospective comparative study. Am J Surg. 2020;219:123-8.

E35. Stenstra MHBC, van Workum F, van den Wildenberg FJH, Polat F, Rosman C. Evolution of the surgical technique of minimally invasive Ivor-Lewis esophagectomy: description according to the IDEAL framework. Dis Esophagus. 2018;32:doy079.

E36. Stilidi I, Davydov M, Bokhyan V, Suleymanov E. Subtotal esophagectomy with extended 2-field lymph node dissection for thoracic esophageal cancer. Eur J Cardiothorac Surg. 2003;23:415-20.

E37. Straatman J, van der Wielen N, Cuesta MA, Daams F, Roig Garcia J, Bonavina L, et al. Minimally invasive versus open esophageal resection: three-year follow-up of the previously reported randomized controlled trial: the TIME trial. Ann Surg. 2017;266:232-6.

E38. Strosberg DS, Merritt RE, Perry KA. Preventing anastomotic complications: early results of laparoscopic gastric devascularization two weeks prior to minimally invasive esophagectomy. Surg Endosc. 2017;31:1371-5.

E39. Suttie SA, Nanthakumaran S, Mofidi R, Rapson T, Gilbert FJ, Thompson AM, et al. The impact of operative approach for oesophageal cancer on outcome: the transhiatal approach may influence circumferential margin involvement. Eur J Surg Oncol. 2012;38:157-65.

E40. Tapias LF, Morse CR. Minimally invasive Ivor Lewis esophagectomy: description of a learning curve. J Am Coll Surg. 2014;218:1130-40.

E41. Tapias LF, Mathisen DJ, Wright CD, Wain JC, Gaissert HA, Muniappan A, et al. Outcomes with open and minimally invasive Ivor Lewis esophagectomy after neoadjuvant therapy. Ann Thorac Surg. 2016;101:1097-103.

E42. Trugeda S, Fernández-Díaz MJ, Rodríguez-Sanjuán JC, Palazuelos CM, Fernández-Escalante C, Gómez-Fleitas M. Initial results of robot-assisted 
Ivor-Lewis oesophagectomy with intrathoracic hand-sewn anastomosis in the prone position. Int J Med Robot. 2014;10:397-403.

E43. van Workum F, Slaman AE, van Berge Henegouwen MI, Gisbertz SS, Kouwenhoven EA, van Det MJ, et al. Propensity score-matched analysis comparing minimally invasive Ivor Lewis versus minimally invasive Mckeown esophagectomy. Ann Surg. 2020;271:128-33.

E44. Wang F, Zhang H, Zheng Y, Wang Z, Geng Y, Wang Y. Intrathoracic side-toside esophagogastrostomy with a linear stapler and barbed suture in robotassisted Ivor Lewis esophagectomy. J Surg Oncol. 2019;120:1142-7.

E45. Wang L, Milman S, Ng T. Performance of the transoral circular stapler for oesophagogastrectomy after induction therapy. Interact Cardiovasc Thorac Surg. 2019;29:890-6.

E46. Woodard GA, Crockard JC, Clary-Macy C, Zoon-Besselink CT, Jones K, Korn WM, et al. Hybrid minimally invasive Ivor Lewis esophagectomy after neoadjuvant chemoradiation yields excellent long-term survival outcomes with minimal morbidity. J Surg Oncol. 2016;114:838-47.

E47. Wu J, Chai Y, Zhou XM, Chen QX, Yan FL. Ivor Lewis subtotal esophagectomy with two-field lymphadenectomy for squamous cell carcinoma of the lower thoracic esophagus. World J Gastroenterol. 2008;14:5084-9.

E48. Wu Z, Wu M, Wang Q, Zhan T, Wang L, Pan S, et al. Home enteral nutrition after minimally invasive esophagectomy can improve quality of life and reduce the risk of malnutrition. Asia Pac J Clin Nutr. 2018;27:129-36.

E49. Zhan B, Chen J, Du S, Xiong Y, Liu J. Using the hand-sewn purse-string stapled anastomotic technique for minimally invasive Ivor Lewis esophagectomy. Thorac Cardiovasc Surg. 2019;67:578-84.

E50. Zhao Y, Jiao W, Zhao J, Wang X, Luo Y, Wang Y. Anastomosis in minimally invasive Ivor Lewis esophagectomy via two ports provides equivalent perioperative outcomes to open. Indian J Cancer. 2015;51(Suppl 2):e25-8.

E51. Kukar M, Ben-David K, Peng JS, Attwood K, Thomas RM, Hennon M, et al. Minimally invasive Ivor Lewis esophagectomy with linear stapled anastomosis associated with low leak and stricture rates. J Gastrointest Surg. 2020;24:1729-35.

E52. Shen X, Chen T, Shi X, Zheng M, Zhou ZY, Qiu HT, et al. Modified reversepuncture anastomotic technique vs. traditional technique for total minimally invasive Ivor-Lewis esophagectomy. World J Surg Oncol. 2020;18:325.

E53. Souche R, Nayeri M, Chati R, Huet E, Donici I, Tuech JJ, et al. Thoracoscopy in prone position with two-lung ventilation compared to conventional thoracotomy during Ivor Lewis procedure: a multicenter case-control study. Surg Endosc. 2020;34:142-52.

E54. Tagkalos E, Goense L, Hoppe-Lotichius M, Ruurda JP, Babic B, Hadzijusufovic E, et al. Robot-assisted minimally invasive esophagectomy (RAMIE) compared to conventional minimally invasive esophagectomy (MIE) for esophageal cancer: a propensity-matched analysis. Dis Esophagus. 2020;33:doz060.

E55. Wang WP, Chen LQ, Zhang HL, Yang YS, He SL, Yuan Y, et al. Modified intrathoracic esophagogastrostomy with minimally invasive robot-assisted Ivor-Lewis esophagectomy for cancer. Dig Surg. 2019;36:218-25.

E56. Zhang H, Wang Z, Zheng Y, Geng Y, Wang F, Chen LQ, et al. Robotic side-toside and end-to-side stapled esophagogastric anastomosis of Ivor Lewis esophagectomy for cancer. World J Surg. 2019;43:3074-82.

E57. Ambrus R, Svendsen LB, Secher NH, Rünitz K, Frederiksen HJ, Svendsen MB, et al. A reduced gastric corpus microvascular blood flow during Ivor-Lewis esophagectomy detected by laser speckle contrast imaging technique. Scand J Gastroenterol. 2017;52:455-61.

E58. Asti E, Bernardi D, Bonitta G, Bonavina L. Outcomes of transhiatal and intercostal pleural drain after Ivor Lewis esophagectomy: comparative analysis of two consecutive patient cohorts. J Laparoendosc Adv Surg Tech A. 2018;28: 574-8.

E59. Berkelmans GHK, Fransen L, Weijs TJ, Lubbers M, Nieuwenhuijzen GAP, Ruurda JP, et al. The long-term effects of early oral feeding following minimal invasive esophagectomy. Dis Esophagus. 2018;31:1-8.

E60. Berlth F, Plum PS, Chon SH, Gutschow CA, Bollschweiler E, Hölscher AH. Total minimally invasive esophagectomy for esophageal adenocarcinoma reduces postoperative pain and pneumonia compared to hybrid esophagectomy. Surg Endosc. 2018;32:4957-65.

E61. Bizekis C, Kent MS, Luketich JD, Buenaventura PO, Landreneau RJ, Schuchert MJ, et al. Initial experience with minimally invasive Ivor Lewis esophagectomy. Ann Thorac Surg. 2006;82:402-6; discussion: 406-7.

E62. Bjelovic M, Babic T, Spica B, Gunjic D, Veselinovic M, Trajkovic G. Could hybrid minimally invasive esophagectomy improve the treatment results of esophageal cancer? Eur J Surg Oncol. 2016;42:1196-201.
E63. Blackmon SH, Correa AM, Wynn B, Hofstetter WL, Martin LW, Mehran RJ, et al. Propensity-matched analysis of three techniques for intrathoracic esophagogastric anastomosis. Ann Thorac Surg. 2007;83:1805-13; discussion: 1813.

E64. Blank S, Schmidt T, Heger P, Strowitzki MJ, Sisic L, Heger U, et al. Surgical strategies in true adenocarcinoma of the esophagogastric junction (AEG II): thoracoabdominal or abdominal approach? Gastric Cancer. 2018;21:303-14.

E65. Bludau M, Hölscher AH, Vallböhmer D, Metzger R, Bollschweiler E, Schröder W. Vascular endothelial growth factor expression following ischemic conditioning of the gastric conduit. Dis Esophagus. 2013;26:847-52.

E66. Bongiolatti S, Annecchiarico M, Di Marino M, Boffi B, Borgianni S, Gonfiotti A, et al. Robot-sewn Ivor-Lewis anastomosis: preliminary experience and technical details. Int J Med Robot. 2015;12:421-6.

E67. Cerfolio RJ, Bryant AS, Canon CL, Dhawan R, Eloubeidi MA. Is botulinum toxin injection of the pylorus during Ivor Lewis [corrected] esophagogastrectomy the optimal drainage strategy? J Thorac Cardiovasc Surg. 2009;137: 565-72.

E68. Chen G, Wang Z, Liu XY, Liu FY. Recurrence pattern of squamous cell carcinoma in the middle thoracic esophagus after modified Ivor-Lewis esophagectomy. World J Surg. 2007;31:1107-14

E69. D'Journo XB, Doddoli C, Michelet P, Loundou A, Trousse D, Giudicelli R, et al. Transthoracic esophagectomy for adenocarcinoma of the oesophagus: standard versus extended two-field mediastinal lymphadenectomy? Eur J Cardiothorac Surg. 2005;27:697-704.

E70. Duan XF, Yue J, Tang P, Shang XB, Jiang HJ, Yu ZT. Lymph node dissection for Siewert II esophagogastric junction adenocarcinoma: a retrospective study of 3 surgical procedures. Medicine (Baltimore). 2017;96:e6120.

E71. Fares KM, Mohamed SA, Hamza HM, Sayed DM, Hetta DF. Effect of thoracic epidural analgesia on pro-inflammatory cytokines in patients subjected to protective lung ventilation during Ivor Lewis esophagectomy. Pain Physician. 2014; 17:305-15.

E72. Findlay L, Yao C, Bennett DH, Byrom R, Davies N. Non-inferiority of minimally invasive oesophagectomy: an 8-year retrospective case series. Surg Endosc. 2017;31:3681-9.

E73. Fritz S, Feilhauer K, Schaudt A, Killguss H, Esianu E, Hennig R, et al. Pylorus drainage procedures in thoracoabdominal esophagectomy - a single-center experience and review of the literature. BMC Surg. 2018;18:13.

E74. Grimminger PP, Tagkalos E, Hadzijusufovic E, Corvinus F, Babic B, Lang H. Change from hybrid to fully minimally invasive and robotic esophagectomy is possible without compromises. Thorac Cardiovasc Surg. 2019;67:589-96.

E75. Hamouda AH, Forshaw MJ, Tsigritis K, Jones GE, Noorani AS, Rohatgi A, et al. Perioperative outcomes after transition from conventional to minimally invasive Ivor-Lewis esophagectomy in a specialized center. Surg Endosc. 2010;24:865-9.

E76. Hawasli A, Camero L, Williams T, Ambrosi G, Sahly M, Demos D, et al. The original Ivor Lewis two stage esophagectomy revisited in the era of minimally invasive surgery. Am J Surg. 2019;217:454-7. https://doi.org/10.1016/j. amjsurg.2018.11.037

E77. Homesh NA, Alsabahi AA, Al-Agmar MH, Alwashaly AA, Valenzuela RE, Alhadid MA, et al. Transhiatal versus transthoracic resection for oesophageal carcinoma in Yemen. Singapore Med J. 2006;47:54-9.

E78. Hummel R, Mees ST, Smith L, Jamieson GG, Kiroff G, Shenfine J. Quality and outcomes of synchronous two-team Ivor-Lewis oesophagectomy: revisiting a variant technique. J Surg Oncol. 2016;114:719-24.

E79. Jensen LS, Pilegaard HK, Puho E, Pahle E, Melsen NC. Outcome after transthoracic resection of carcinoma of the oesophagus and oesophago-gastric junction. Scand J Surg. 2005;94:191-6.

E80. Kauppi J, Räsänen J, Sihvo E, Huuhtanen R, Nelskylä K, Salo J. Open versus minimally invasive esophagectomy: clinical outcomes for locally advanced esophageal adenocarcinoma. Surg Endosc. 2015;29:2614-9.

E81. Kawoosa NU, Dar AM, Sharma ML, Ahangar AG, Lone GN, Bhat MA, et al. Transthoracic versus transhiatal esophagectomy for esophageal carcinoma: experience from a single tertiary care institution. World J Surg. 2011;35: 1296-302.

E82. Lee JJ, Kim GH, Kim JA, Yang M, Ahn HJ, Sim WS, et al. Comparison of pulmonary morbidity using sevoflurane or propofol-remifentanil anesthesia in an Ivor Lewis operation. J Cardiothorac Vasc Anesth. 2012;26:857-62.

E83. Li B, Xiang J, Zhang Y, Li H, Zhang J, Sun Y, et al. Comparison of Ivor-Lewis vs Sweet esophagectomy for esophageal squamous cell carcinoma. JAMA Surg. 2015;150:292. 
E84. Li H, Hu B, You B, Miao JB, Fu YL, Chen QR. Combined laparoscopic and thoracoscopic Ivor Lewis esophagectomy for esophageal cancer: initial experience from China. Chin Med J (Engl). 2012;125:1376-80.

E85. Lindner K, Fritz M, Haane C, Senninger N, Palmes D, Hummel R. Postoperative complications do not affect long-term outcome in esophageal cancer patients. World J Surg. 2014;38:2652-61.

E86. Luketich JD, Pennathur A, Awais O, Levy RM, Keeley S, Shende M, et al. Outcomes after minimally invasive esophagectomy: review of over 1000 patients. Ann Surg. 2012;256:95-103.

E87. Ma J, Zhan C, Wang L, Jiang W, Zhang Y, Shi Y, et al. The sweet approach is still worthwhile in modern esophagectomy. Ann Thorac Surg. 2014;97: 1728-33.

E88. Malaisrie SC, Untch B, Aranha GV, Mohideen N, Hantel A, Pickleman J. Neoadjuvant chemoradiotherapy for locally advanced esophageal cancer: experience at a single institution. Arch Surg. 2004;139:532-8; discussion: 538-9.

E89. Mariette C, Markar SR, Dabakuyo-Yonli TS, Meunier B, Pezet D, Collet D, et al. Hybrid minimally invasive esophagectomy for esophageal cancer. $N$ Engl J Med. 2019;380:152-62.

E90. McCahill LE, May M, Morrow JB, Khandavalli S, Shabahang B, Kemmeter P, et al. Esophagectomy outcomes at a mid-volume cancer center utilizing prospective multidisciplinary care and a 2-surgeon team approach. Am J Surg. 2014;207:380-6; discussion: 385-6.

E91. Mei X, Xu M, Guo M, Xie M, Liu C, Wang Z. Minimally invasive Ivor-Lewis oesophagectomy is a feasible and safe approach for patients with oesophageal cancer. ANZ J Surg. 2015;86:274-9.

E92. Meredith K, Blinn P, Maramara T, Takahashi C, Huston J, Shridhar R. Comparative outcomes of minimally invasive and robotic-assisted esophagectomy. Surg Endosc. 2020;34:814-20.

E93. Mu J, Yuan Z, Zhang B, Li N, Lyu F, Mao Y, et al. Comparative study of minimally invasive versus open esophagectomy for esophageal cancer in a single cancer center. Chin Med J (Engl). 2014;127:747-52.

E94. Mungo B, Lidor AO, Stem M, Molena D. Early experience and lessons learned in a new minimally invasive esophagectomy program. Surg Endosc. 2016;30: 1692-8.

E95. Pan S, Wang L, Wu M, Wang Q, Shen G, Chen G. A single intercostal space thoracoscopic approach for minimally invasive Ivor Lewis esophagectomy. $J$ Laparoendosc Adv Surg Tech A. 2017;27:1198-202.

E96. Peng J, Wang WP, Yuan Y, Hu Y, Wang Y, Chen LQ. Optimal extent of lymph node dissection for Siewert type II esophagogastric junction adenocarcinoma. Ann Thorac Surg. 2015;100:263-9.

E97. Pham TH, Perry KA, Dolan JP, Schipper P, Sukumar M, Sheppard BC, et al. Comparison of perioperative outcomes after combined thoracoscopiclaparoscopic esophagectomy and open Ivor-Lewis esophagectomy. Am J Surg. 2010;199:594-8.

E98. Schröder W, Bollschweiler E, Kossow C, Hölscher AH. Preoperative risk analysis-a reliable predictor of postoperative outcome after transthoracic esophagectomy? Langenbecks Arch Surg. 2006;391:455-60.

E99. Sihag S, Wright CD, Wain JC, Gaissert HA, Lanuti M, Allan JS, et al. Comparison of perioperative outcomes following open versus minimally invasive Ivor Lewis oesophagectomy at a single, high-volume centre. Eur J Cardiothorac Surg. 2012;42:430-7.

E100. Thomay AA, Snyder JA, Edmondson DM, Scott WJ. Initial results of minimally invasive Ivor Lewis esophagectomy after induction chemoradiation (50.4 Gy) for esophageal cancer. Innovations (Phila). 2012;7:421-8.

E101. Valmasoni M, Capovilla G, Pierobon ES, Moletta L, Provenzano L, Costantini M, et al. A technical modification to the circular stapling anastomosis technique during minimally invasive Ivor Lewis procedure. J Laparoendosc Adv Surg Tech A. 2019;29:1585-91.

E102. Vande Walle C, Ceelen WP, Boterberg T, Vande Putte D, Van Nieuwenhove Y, Varin $\mathrm{O}$, et al. Anastomotic complications after Ivor Lewis esophagectomy in patients treated with neoadjuvant chemoradiation are related to radiation dose to the gastric fundus. Int J Radiat Oncol Biol Phys. 2012;82:e513-9.

E103. Wang J, Wei N, Jiang N, Lu Y, Zhang X. Comparison of Ivor-Lewis versus Sweet procedure for middle and lower thoracic esophageal squamous cell carcinoma: a STROBE compliant study. Medicine (Baltimore). 2019;98:e14416.

E104. Wee JO, Bravo-Iñiguez CE, Jaklitsch MT. Early experience of robot-assisted esophagectomy with circular end-to-end stapled anastomosis. Ann Thorac Surg. 2016;102:253-9.

E105. Wu W, Zhu Q, Chen L, Liu J. Technical and early outcomes of Ivor Lewis minimally invasive oesophagectomy for gastric tube construction in the thoracic cavity. Interact Cardiovasc Thorac Surg. 2014;18:86-91.
E106. Xie MR, Liu CQ, Guo MF, Mei XY, Sun XH, Xu MQ. Short-term outcomes of minimally invasive Ivor-Lewis esophagectomy for esophageal cancer. Ann Thorac Surg. 2014;97:1721-7.

E107. Yin Q, Wang W, Liu H, Yang G, Zhou S, Liu L. Clinical application and observation of modified Ivor-Lewis surgery in Siewert type II adenocarcinoma of the esophagogastric junction. J Cardiothorac Surg. 2019;14:207.

E108. Yoshimura S, Mori K, Yamagata Y, Aikou S, Yagi K, Nishida M, et al. Quality of life after robot-assisted transmediastinal radical surgery for esophageal cancer. Surg Endosc. 2018;32:2249-54.

E109. Yu Y, Wang Z, Liu XY, Zhu XF, Chen QF. Therapeutic efficacy comparison of two surgical procedures to treat middle thoracic esophageal carcinoma. World J Surg. 2010;34:272-6.

E110. Liu Y, Li JJ, Zu P, Liu HX, Yu ZW, Ren Y. Two-step method for creating a gastric tube during laparoscopic-thoracoscopic Ivor-Lewis esophagectomy. World J Gastroenterol. 2017;23:8035-43.

E111. Zhang Y, Xiang J, Han Y, Huang M, Hang J, Abbas AE, et al. Initial experience of robot-assisted Ivor-Lewis esophagectomy: 61 consecutive cases from a single Chinese institution. Dis Esophagus. 2018;31.

E112. Zhang Z, Xu M, Guo M, Liu X. Long-term outcomes of minimally invasive Ivor Lewis esophagostomy for esophageal squamous cell carcinoma: compared with open approach. Int J Surg. 2017;45:98-104.

E113. Awad ZT, Abbas S, Puri R, Dalton B, Chesire DJ. Minimally invasive Ivo Lewis esophagectomy (MILE): technique and outcomes of 100 consecutive cases. Surg Endosc. 2020;34:3243-55.

E114. Berlth F, Mann C, Uzun E, Tagkalos E, Hadzijusufovic E, Hillegersberg R et al. Technical details of the abdominal part during full robotic-assisted minimally invasive esophagectomy. Dis Esophagus. 2020;33(Suppl 2):doaa084.

E115. Egberts JH, Stein H, Aselmann H, Hendricks A, Becker T. Fully robotic da Vinci Ivor-Lewis esophagectomy in four-arm technique-problems and solutions. Dis Esophagus. 2017;30:1-9.

E116. Gao HJ, Mu JW, Pan WM, Brock M, Wang ML, Han B, et al. Totally mechanical linear stapled anastomosis for minimally invasive Ivor Lewis esophagectomy: operative technique and short-term outcomes. Thorac Cancer. 2020;11: 769-77.

E117. Hernandez JM, Dimou F, Weber J, Almhanna K, Hoffe S, Shridhar R, et al Defining the learning curve for robotic-assisted esophagogastrectomy. J Gastrointest Surg. 2013;17:1346-51.

E118. Jeon HW, Park JK, Song KY, Sung SW. High intrathoracic anastomosis with thoracoscopy is safe and feasible for treatment of esophageal squamous cell carcinoma. PLoS One. 2016;11:e0152151.

E119. Merritt RE, Kneuertz PJ, D’Souza DM, Abdel-Rasoul M, Perry KA. An analysis of outcomes after transition from open to minimally invasive Ivor Lewis esophagectomy. Ann Thorac Surg. 2021;111:1174-81.

E120. Pötscher A, Bittermann C, Längle F. Robot-assisted esophageal surgery using the da Vinci ${ }^{\circledR}$ Xi system: operative technique and initial experiences. J Robot Surg. 2019;13:469-74.

E121. Wang Z, Zhang H, Wang F, Wang Y. Robot-assisted esophagogastric reconstruction in minimally invasive Ivor Lewis esophagectomy. J Thorac Dis. 2019;11:1860-6.

E122. Zhang T, Hou X, Li Y, Fu X, Liu L, Xu L, et al. Effectiveness and safety of minimally invasive Ivor Lewis and McKeown oesophagectomy in Chinese patients with stage IA-IIIB oesophageal squamous cell cancer: a multicentre, non-interventional and observational study. Interact Cardiovasc Thorac Surg. 2020;30:812-9.

E123. Hulscher JB, van Sandick JW, de Boer AG, Wijnhoven BP, Tijssen JG, Fockens $\mathrm{P}$, et al. Extended transthoracic resection compared with limited transhiatal resection for adenocarcinoma of the esophagus. N Engl J Med. 2002; 347:1662-9.

E124. Luketich JD, Schauer PR, Christie NA, Weigel TL, Raja S, Fernando HC, et al Minimally invasive esophagectomy. Ann Thorac Surg. 2000;70:906-11; discussion: 911-2.

E125. Biere SS, van Berge Henegouwen MI, Maas KW, Bonavina L, Rosman C, Garcia JR, et al. Minimally invasive versus open oesophagectomy for patients with oesophageal cancer: a multicentre, open-label, randomised controlled trial. Lancet. 2012;379:1887-92.

E126. van der Sluis PC, van der Horst S, May AM, Schippers C, Brosens LAA Joore HCA, et al. Robot-assisted minimally invasive thoracolaparoscopic esophagectomy versus open transthoracic esophagectomy for resectable esophageal cancer: a randomized controlled trial. Ann Surg. 2019;269:621-30.

E127. Espinoza-Mercado F, Imai TA, Borgella JD, Sarkissian A, Serna-Gallegos D Alban RF, et al. Does the approach matter? Comparing survival in robotic, 
minimally invasive and open esophagectomies. Ann Thorac Surg. 2019;107: 378-85.

E128. Yun JS, Na KJ, Song SY, Kim S, Jeong IS, Oh SG. Comparison of perioperative outcomes following hybrid minimally invasive versus open Ivor Lewis esophagectomy for esophageal cancer. J Thorac Dis. 2017;9:3097-104.

E129. Messager M, Pasquer A, Duhamel A, Caranhac G, Piessen G, Mariette C, et al. Laparoscopic gastric mobilization reduces postoperative mortality after esophageal cancer surgery: a French nationwide study. Ann Surg. 2015;262: 817-22; discussion: 822-3.

E130. Veenstra MMK, Smithers BM, Visser E, Edholm D, Brosda S, Thomas JM, et al. Complications and survival after hybrid and fully minimally invasive oesophagectomy. BJS Open. 2021;5:zraa033.

E131. Irino T, Tsai JA, Ericson J, Nilsson M, Lundell L, Rouvelas I. Thoracoscopic side-to-side esophagogastrostomy by use of linear stapler-a simplified technique facilitating a minimally invasive Ivor-Lewis operation. Langenbecks Arch Surg. 2016;401:315-22.

E132. Gottlieb-Vedi E, Kauppila JH, Malietzis G, Nilsson M, Markar SR, Lagergren J. Long-term survival in esophageal cancer after minimally invasive compared to open esophagectomy: a systematic review and meta-analysis. Ann Surg. 2019;270:1005-17.

E133. Schoppmann SF, Prager G, Langer FB, Riegler FM, Kabon B, Fleischmann E, et al. Open versus minimally invasive esophagectomy: a single-center case controlled study. Surg Endosc. 2010;24:3044-53.

E134. Yibulayin W, Abulizi S, Lv H, Sun W. Minimally invasive oesophagectomy versus open esophagectomy for resectable esophageal cancer: a meta-analysis. World J Surg Oncol. 2016;14:304.
E135. Sihag S, Kosinski AS, Gaissert HA, Wright CD, Schipper PH. Minimally invasive versus open esophagectomy for esophageal cancer: a comparison of early surgical outcomes from the Society of Thoracic Surgeons national database. Ann Thorac Surg. 2016;101:1281-8.

E136. van Workum F, Stenstra MHBC, Berkelmans GHK, Slaman AE, van Berge Henegouwen MI, Gisbertz SS, et al. Learning curve and associated morbidity of minimally invasive esophagectomy: a retrospective multicenter study. Ann Surg. 2019;269:88-94.

E137. Claassen L, van Workum F, Rosman C. Learning curve and postoperative outcomes of minimally invasive esophagectomy. J Thorac Dis. 2019;11(Suppl 5): S777-85.

E138. Fumagalli U, Baiocchi GL, Celotti A, Parise P, Cossu A, Bonavina L, et al. Incidence and treatment of mediastinal leakage after esophagectomy: insights from the multicenter study on mediastinal leaks. World J Gastroenterol. 2019; 25:356-66.

E139. Nguyen NT, Follette DM, Wolfe BM, Schneider PD, Roberts P, Goodnight JE Jr. Comparison of minimally invasive esophagectomy with transthoracic and transhiatal esophagectomy. Arch Surg. 2000;135: 920-5.

E140. Wang Q, Wu Z, Zhan T, Fang S, Zhang S, Shen G, et al. Comparison of minimally invasive Ivor Lewis esophagectomy and left transthoracic esophagectomy in esophageal squamous cell carcinoma patients: a propensity scorematched analysis. BMC Cancer. 2019;19:500

E141. Akowuah E, Junemann-Ramirez M, Kalejayie O, Rahamim J. Inkwelling increases benign stricture formation after Ivor Lewis esophagogastrectomy. $J$ Thorac Cardiovasc Surg. 2007;133:581-2. 


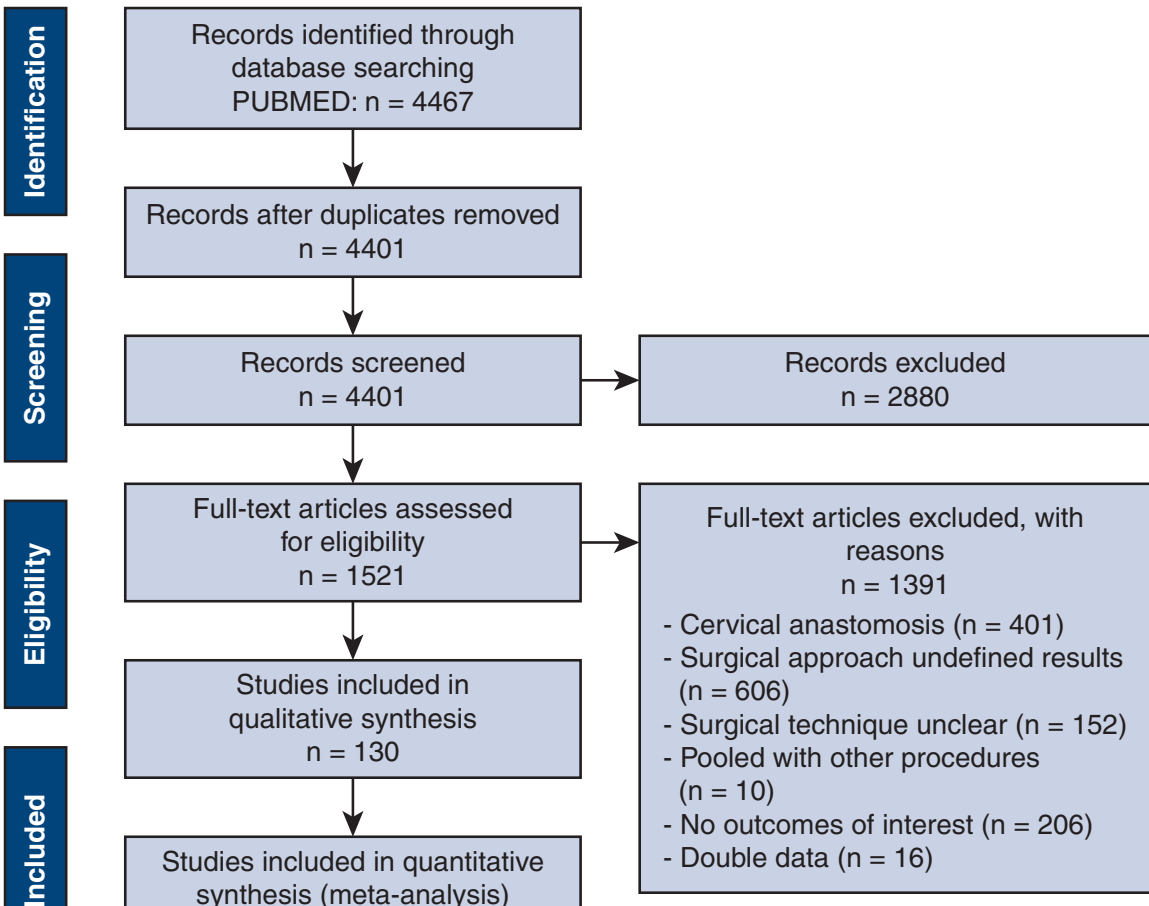

FIGURE E1. Selection process in accordance with the Preferred Reporting Items for Systematic Reviews and Meta-analyses.
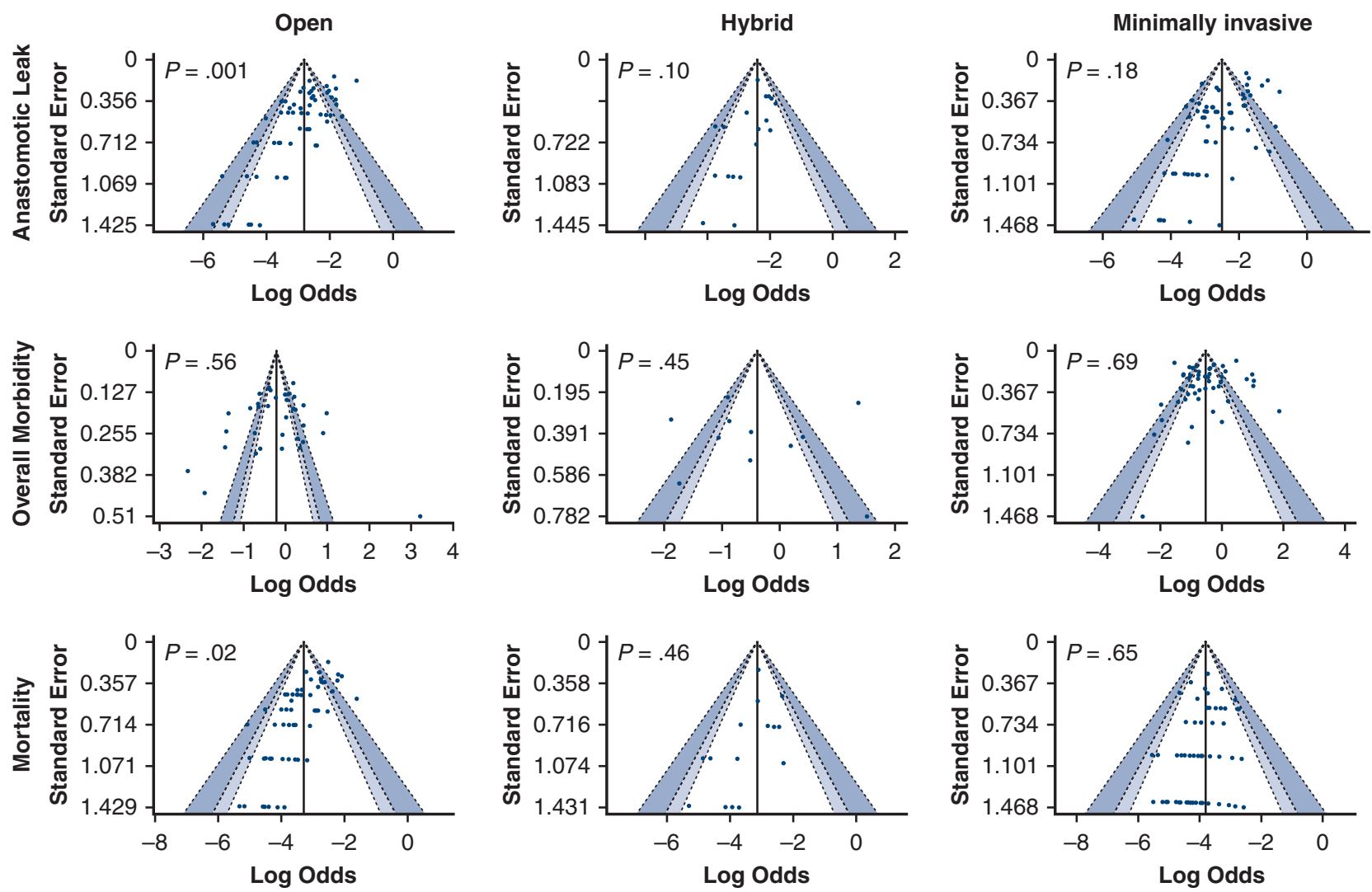

FIGURE E2. Funnel plots assessing publication bias for the main outcomes of the study among open, hybrid, and totally minimally invasive esophagectomy. 
TABLE E1. Characteristics of studies with patients undergoing open Ivor Lewis esophagectomy

\begin{tabular}{|c|c|c|c|c|c|c|c|c|c|c|}
\hline $\begin{array}{l}\text { First author } \\
\text { reference }\end{array}$ & Design & $\begin{array}{c}\text { Patient } \\
\text { N }\end{array}$ & $\begin{array}{c}\text { Median } \\
\text { age, } \\
\text { years }\end{array}$ & $\begin{array}{c}\text { Male } \\
\text { sex, } \%\end{array}$ & $\begin{array}{c}\text { Neoadjuvant } \\
\text { therapy, } \%\end{array}$ & $\begin{array}{c}\text { Mean } \\
\text { operative } \\
\text { time, } \\
\text { minutes }\end{array}$ & $\begin{array}{c}\text { Anastomotic } \\
\text { leak, } \%\end{array}$ & $\begin{array}{c}\text { Overall } \\
\text { morbidity, } \\
\%\end{array}$ & $\begin{array}{c}\text { Mortality, } \\
\%\end{array}$ & $\begin{array}{c}\text { Median } \\
\text { LOS, } \\
\text { days }\end{array}$ \\
\hline $\operatorname{Karl}^{\mathrm{E} 17}$ & Retrospective & 143 & 63.7 & 88.8 & 19.6 & 327 & 3.5 & 29 & 2.1 & 13.5 \\
\hline Griffin $^{\mathrm{E} 10}$ & Retrospective & 228 & 64 & NA & 2.6 & 257 & 1.8 & 52.2 & 2.2 & 13 \\
\hline Stilidi ${ }^{\mathrm{E} 6}$ & Retrospective & 147 & 57 & 76.9 & 0 & NA & 0 & 60.6 & 6.1 & NA \\
\hline Malaisrie $^{\mathrm{E} 88}$ & Retrospective & 123 & 62 & 83.7 & 25.2 & NA & 4.1 & 56.1 & 2.4 & 14 \\
\hline D’Journo $^{\text {E69 }}$ & Retrospective & 102 & 62 & 88.2 & 52.9 & NA & 1 & NA & 9.8 & 28 \\
\hline Jensen $^{\mathrm{E} 79}$ & Retrospective & 166 & 62 & 71.7 & 8.4 & 170 & 1.2 & NA & 6 & 11 \\
\hline $\begin{array}{l}\text { Junemann- } \\
\text { Ramirez }^{\mathrm{E} 15}\end{array}$ & Retrospective & 276 & 66.1 & 68.1 & 6.2 & NA & 5.1 & NA & 5.8 & NA \\
\hline Homesh $^{\mathrm{E} 77}$ & Prospective & 41 & 59 & 46.3 & NA & NA & 12 & NA & 7.3 & 21.7 \\
\hline Robertson ${ }^{\mathrm{E} 29}$ & Retrospective & 71 & NA & NA & NA & NA & 14.1 & 32.4 & 8.5 & NA \\
\hline Schröder ${ }^{\mathrm{E} 98}$ & Retrospective & 126 & 58.2 & 84.1 & 36.5 & NA & 11.1 & 54 & 5.6 & NA \\
\hline Blackmon $^{\mathrm{E} 63}$ & Retrospective & 214 & 58 & 91.1 & 77 & NA & 7 & NA & NA & 12 \\
\hline Akowuah $^{\text {E141 }}$ & Retrospective & 495 & 66 & NA & NA & NA & 6.7 & NA & 7.5 & NA \\
\hline Chen $^{\text {E68 }}$ & Retrospective & 196 & 54 & 67.3 & 0 & NA & 6.6 & 33.7 & 2.5 & NA \\
\hline Kono $^{\mathrm{E} 21}$ & Retrospective & 76 & 70 & 92.1 & 0 & 500 & 1.3 & NA & 1.3 & NA \\
\hline Cerfolio $^{\mathrm{E} 67}$ & Retrospective & 221 & 64 & 62.9 & 52 & 234 & 0.5 & 49.8 & 4.5 & 8 \\
\hline Luechakiettisak $^{\mathrm{E} 22}$ & Prospective & 117 & 63 & 83.7 & NA & 210 & 5.12 & NA & 11.1 & NA \\
\hline $\mathrm{Raz}^{\mathrm{E} 28}$ & Retrospective & 33 & 62 & 69.7 & 15.2 & NA & 0 & NA & 3 & NA \\
\hline Safranek $^{\mathrm{E} 30}$ & Retrospective & 40 & NA & NA & NA & NA & 2.5 & NA & 0 & NA \\
\hline $\mathrm{Wu}^{\mathrm{E} 47}$ & Retrospective & 73 & 57 & 89 & 0 & 243 & 2.7 & 15.4 & 2.7 & NA \\
\hline $\mathrm{Ott}^{\mathrm{E} 27}$ & Retrospective & 240 & 59 & 94.6 & 65.4 & NA & 7.5 & NA & 2.1 & NA \\
\hline Hamouda $^{\mathrm{E75}}$ & Retrospective & 24 & 60 & 89.3 & 83.3 & 260 & 8.3 & NA & 0 & 14 \\
\hline Pham $^{\text {E97 }}$ & Retrospective & 46 & 61 & 71.7 & 50 & 437 & 10.9 & 58.7 & 4.3 & 14 \\
\hline Munitiz $^{\text {E24 }}$ & Retrospective & 148 & 60 & 87.2 & 7.4 & NA & 7.4 & 34.5 & 3.4 & 11 \\
\hline $\mathrm{Yu}^{\mathrm{E} 109}$ & Retrospective & 102 & NA & 72.5 & NA & NA & 0 & 19.6 & 0 & NA \\
\hline Asteriou $^{22}$ & Retrospective & 114 & 61 & 59.6 & 0 & 345 & 7.9 & NA & 4.4 & 11 \\
\hline Kawoosa $^{\mathrm{E} 81}$ & Retrospective & 177 & 57 & 67.2 & NA & 234 & 2.8 & 50.8 & 3.4 & 11.2 \\
\hline Vande Walle ${ }^{\mathrm{E} 102}$ & Retrospective & 54 & 59 & 85.2 & 100 & 384 & 9.3 & NA & 5.6 & 17.5 \\
\hline Klink $^{\text {E20 }}$ & Retrospective & 36 & 62 & 94.4 & 72.2 & 261 & 11.1 & NA & 2.8 & 14 \\
\hline $\mathrm{Lee}^{\mathrm{E} 82}$ & Retrospective & 48 & 62 & 100 & 12.6 & 270 & 6.25 & 35.4 & 0 & 15 \\
\hline Noble ${ }^{\mathrm{E} 26}$ & Retrospective & 53 & 64 & 84.9 & 67.9 & 240 & 3.8 & 60.4 & 1.9 & 12 \\
\hline Sayir $^{\mathrm{E} 32}$ & Retrospective & 60 & 52.7 & 43.3 & NA & 286 & 5 & 48.3 & 5 & 14 \\
\hline Sihag $^{\text {E99 }}$ & Retrospective & 76 & 63.3 & 80.3 & 60.5 & 365 & 2.6 & 71 & 2.6 & 9 \\
\hline Suttie ${ }^{\mathrm{E} 39}$ & Retrospective & 140 & 64 & 66.4 & 9.3 & NA & 7.1 & NA & 10 & 21 \\
\hline Beasley $^{23}$ & Retrospective & 165 & 66 & 78.8 & 41.2 & NA & 1.2 & NA & 3 & 15 \\
\hline Fares $^{\mathrm{E} 71}$ & Retrospective & 30 & 56 & 76.6 & NA & 269 & 16.6 & NA & 16.6 & NA \\
\hline Kauppi $^{\mathrm{E} 80}$ & Retrospective & 79 & 63 & 86 & 100 & 367 & 6.3 & 60.8 & 1.3 & 13 \\
\hline Lindner $^{\mathrm{E} 85}$ & Retrospective & 134 & 63 & 82.8 & 58.2 & 275 & 14.2 & 53 & 6.7 & 21 \\
\hline $\mathrm{Ma}^{\mathrm{E} 87}$ & Retrospective & 167 & NA & 84.4 & NA & 208 & 4.2 & 20.4 & 1.8 & NA \\
\hline $\mathrm{Mu}^{\mathrm{E} 93}$ & Retrospective & 90 & 59 & 74.4 & NA & 270 & 0 & 8.9 & 1.1 & 19 \\
\hline$X i^{E 106}$ & Retrospective & 163 & 63.8 & 74.2 & 0 & 256 & 3.7 & 34.4 & 2.5 & 13.9 \\
\hline Zhao $^{\text {E50 }}$ & Retrospective & 30 & 57.8 & 93.3 & 0 & NA & 3.3 & NA & 0 & 13 \\
\hline
\end{tabular}


TABLE E1. Continued

\begin{tabular}{|c|c|c|c|c|c|c|c|c|c|c|}
\hline $\begin{array}{c}\text { First author } \\
\text { reference }\end{array}$ & Design & $\begin{array}{c}\text { Patient } \\
\text { N }\end{array}$ & $\begin{array}{c}\text { Median } \\
\text { age, } \\
\text { years }\end{array}$ & $\begin{array}{c}\text { Male } \\
\text { sex, \% }\end{array}$ & $\begin{array}{c}\text { Neoadjuvant } \\
\text { therapy, } \%\end{array}$ & $\begin{array}{c}\text { Mean } \\
\text { operative } \\
\text { time, } \\
\text { minutes }\end{array}$ & $\begin{array}{c}\text { Anastomotic } \\
\text { leak, } \%\end{array}$ & $\begin{array}{c}\text { Overall } \\
\text { morbidity, } \\
\%\end{array}$ & $\begin{array}{c}\text { Mortality, } \\
\%\end{array}$ & $\begin{array}{c}\text { Median } \\
\text { LOS, } \\
\text { days }\end{array}$ \\
\hline Harustiak $^{\mathrm{E} 12}$ & Retrospective & 415 & 61 & 86.7 & 56 & NA & 13.5 & 54.7 & 3.9 & 12 \\
\hline $\mathrm{Li}^{\mathrm{E} 83}$ & Prospective & 150 & 60 & 78.7 & NA & 202 & 1.3 & 30 & 0.7 & 16 \\
\hline Peng ${ }^{\text {E96 }}$ & Retrospective & 31 & 61.2 & 80.6 & NA & NA & 3.2 & NA & NA & 12.4 \\
\hline Ambrus $^{\mathrm{E57}}$ & Retrospective & 25 & 67.5 & 76 & NA & 237 & 8 & NA & 4 & NA \\
\hline Bjelovic $^{\mathrm{E} 62}$ & Prospective & 44 & 59 & 81.8 & NA & 341 & 0 & 47.7 & 2 & 16.6 \\
\hline Deldycke $^{\mathrm{E7}}$ & Retrospective & 322 & 61.7 & 80.4 & 42.5 & NA & 5.6 & NA & NA & NA \\
\hline Hummel $^{\mathrm{E} 78}$ & Retrospective & 201 & 63 & 81.6 & 100 & 205 & 11 & 55 & 3 & 14 \\
\hline $\mathrm{Mei}^{\mathrm{E} 91}$ & Retrospective & 248 & 62.4 & 76.6 & 0 & 261 & 3.2 & 35 & 2 & 12.8 \\
\hline Tapias $^{\mathrm{E} 41}$ & Retrospective & 75 & 62.6 & 89.3 & 100 & 361 & 1.3 & NA & 2.7 & 9 \\
\hline Ahmadi $^{21}$ & Retrospective & 137 & NA & 89 & 59 & 509 & 16 & 73 & 2 & 14 \\
\hline Blank $^{\text {E64 }}$ & Retrospective & 56 & NA & 85.7 & 55.4 & NA & 14.3 & 57.1 & 5.4 & 19 \\
\hline Duan $^{\mathrm{E} 70}$ & Retrospective & 47 & 63.6 & 91.5 & 0 & 223 & 0 & 12.8 & 0 & 15.4 \\
\hline Findlay ${ }^{\mathrm{E} 72}$ & Retrospective & 187 & 65 & 79.3 & 86.2 & NA & 5.8 & NA & 1 & 11 \\
\hline Miller $^{\mathrm{E} 23}$ & Retrospective & 45 & 63 & 88.9 & 60 & NA & 6.7 & 33.3 & 0 & NA \\
\hline Zhang $^{\mathrm{E} 112}$ & Retrospective & 95 & 63.9 & 76.8 & 0 & 271 & 5.2 & 50.5 & 1.1 & 12 \\
\hline Fritz $^{\mathrm{E} 73}$ & Retrospective & 170 & 64 & 80.6 & 65.3 & 256 & 24.1 & NA & 2.9 & 20 \\
\hline Kesler $^{\text {E18 }}$ & Retrospective & 278 & 60 & 82 & 71.9 & NA & 2.9 & 41.4 & 1.1 & 13 \\
\hline $\mathrm{Wu}^{\mathrm{E} 48}$ & Prospective & 75 & 61 & 89 & NA & NA & 2.7 & NA & 1.5 & 16 \\
\hline Mariette $^{\mathrm{E} 89}$ & Prospective & 104 & 62 & 83.5 & 72.1 & 300 & 6.7 & 96 & 2 & 14 \\
\hline Wang $^{\mathrm{E} 103}$ & Retrospective & 325 & 62 & 8.2 & 0 & 165 & 5.5 & 40.3 & 0.6 & 12 \\
\hline Wang $^{\mathrm{E} 45}$ & Retrospective & 87 & 63 & 79.3 & 100 & 300 & 2.3 & NA & 0 & 10 \\
\hline
\end{tabular}

LOS, Length of stay; $N A$, not available. 
TABLE E2. Characteristics of studies with patients who underwent hybrid Ivor Lewis esophagectomy

\begin{tabular}{|c|c|c|c|c|c|c|c|c|c|c|}
\hline $\begin{array}{l}\text { First author } \\
\text { reference }\end{array}$ & Design & $\begin{array}{c}\text { Patient } \\
\text { N }\end{array}$ & $\begin{array}{c}\text { Median } \\
\text { age, years }\end{array}$ & $\begin{array}{c}\text { Male } \\
\text { sex, } \%\end{array}$ & $\begin{array}{l}\text { Neoadjuvant } \\
\text { therapy, } \%\end{array}$ & $\begin{array}{c}\text { Mean } \\
\text { operative } \\
\text { time, minutes }\end{array}$ & $\begin{array}{c}\text { Anastomotic } \\
\text { leak, \% }\end{array}$ & $\begin{array}{c}\text { Overall } \\
\text { morbidity, \% }\end{array}$ & $\begin{array}{c}\text { Mortality, } \\
\%\end{array}$ & $\begin{array}{c}\text { Median } \\
\text { LOS, days }\end{array}$ \\
\hline Bizekis $^{\mathrm{E} 61}$ & Retrospective & 35 & 62 & NA & NA & NA & 8.6 & NA & 5.7 & 9 \\
\hline Godiris-Petit $^{\mathrm{E9}}$ & Prospective & 25 & 60 & 68 & 20 & 260 & 8 & 60 & 8 & 18 \\
\hline Hölscher $^{\mathrm{E} 13}$ & Retrospective & 83 & 61.9 & 81.9 & 50.6 & NA & 6 & 13.3 & NA & NA \\
\hline Hamouda $^{\mathrm{E} 75}$ & Retrospective & 25 & 64 & 76 & 80 & 249 & 12 & NA & 0 & 15 \\
\hline Schröder ${ }^{\mathrm{E} 33}$ & Retrospective & 419 & 59.7 & 83.3 & 50.1 & NA & 8.4 & NA & 4.3 & NA \\
\hline Bludau $^{\mathrm{E} 65}$ & Prospective & 20 & 60.9 & 80 & 70 & NA & 5 & 15 & 0 & NA \\
\hline $\operatorname{Kim}^{\mathrm{E} 19}$ & Retrospective & 31 & 64 & 90.3 & 0 & NA & 0 & 25.8 & 0 & 15.2 \\
\hline McCahill $^{\mathrm{E} 90}$ & Prospective & 11 & NA & NA & NA & 468 & 0 & 81.8 & 9 & 13 \\
\hline Bonavina $^{24}$ & Retrospective & 80 & 63.5 & 88.8 & 21.3 & 300 & 12.5 & NA & 2.5 & 13 \\
\hline Bjelovic $^{\mathrm{E} 62}$ & Prospective & 44 & 61.4 & 84 & NA & 319 & 2.3 & 29.5 & 2.2 & 16.1 \\
\hline Wee $e^{\text {E104 }}$ & Retrospective & 20 & 64 & 70 & 85 & 455 & NA & 55 & 0 & 8 \\
\hline Woodard $^{\mathrm{E} 46}$ & Retrospective & 131 & 66 & 66.4 & NA & NA & 2.3 & NA & 0.8 & 10 \\
\hline Findlay $^{\mathrm{E} 72}$ & Retrospective & 95 & 67 & 88.4 & 82.1 & NA & 11.6 & NA & 4.2 & 12 \\
\hline Yoshimura $^{\text {E108 }}$ & Retrospective & 37 & 69 & 81.1 & 2.7 & NA & 10.8 & NA & NA & NA \\
\hline Asti $^{\mathrm{E} 58}$ & Retrospective & 100 & 63 & 82 & 42 & 335 & 3 & 29 & 0 & 10 \\
\hline Brinkmann $^{25}$ & Retrospective & 154 & 62 & 76 & 80.5 & NA & 9.7 & 63 & 2.6 & 16 \\
\hline Grimminger $^{\mathrm{E} 74}$ & Retrospective & 25 & 60.3 & 84 & 88 & 360 & 4 & NA & 0 & 15.8 \\
\hline Hawasli $^{\text {E76 }}$ & Retrospective & 29 & 62 & 89.7 & NA & NA & 3.4 & 37.9 & 6.9 & 12 \\
\hline Mariette $^{\mathrm{E} 89}$ & Prospective & 103 & 59 & 85.4 & 74.8 & 327 & 10.7 & 78 & 1 & 14 \\
\hline Sdralis $^{\mathrm{E} 34}$ & Prospective & 57 & NA & 71.9 & 64.9 & 320 & 14 & NA & 8.8 & 12 \\
\hline
\end{tabular}

LOS, Length of stay; NA, not available. 
TABLE E3. Characteristics of studies with patients who underwent totally minimally invasive Ivor Lewis esophagectomy

\begin{tabular}{|c|c|c|c|c|c|c|c|c|c|c|}
\hline $\begin{array}{l}\text { First author } \\
\text { reference }\end{array}$ & Design & $\begin{array}{c}\text { Patient } \\
\text { N }\end{array}$ & $\begin{array}{c}\text { Median } \\
\text { age, years }\end{array}$ & $\begin{array}{c}\text { Male } \\
\text { sex, } \%\end{array}$ & $\begin{array}{c}\text { Neoadjuvant } \\
\text { therapy, \% }\end{array}$ & $\begin{array}{c}\text { Mean } \\
\text { operative } \\
\text { time, minutes }\end{array}$ & $\begin{array}{c}\text { Anastomotic } \\
\text { leak, } \%\end{array}$ & $\begin{array}{c}\text { Overall } \\
\text { morbidity, \% }\end{array}$ & $\begin{array}{c}\text { Mortality, } \\
\%\end{array}$ & $\begin{array}{c}\text { Median } \\
\text { LOS, } \\
\text { days }\end{array}$ \\
\hline Bizekis $^{\text {E61 }}$ & Retrospective & 15 & 62 & NA & NA & NA & 0 & NA & 6.6 & 7 \\
\hline Nguyen $^{\mathrm{E} 25}$ & Prospective & 51 & 64 & 64.7 & NA & 249 & 7.8 & NA & 1.9 & 9.7 \\
\hline Campos ${ }^{\mathrm{E} 3}$ & Retrospective & 37 & 65 & 86.5 & 54.1 & 275 & 2.7 & 43.2 & NA & 10 \\
\hline Hamouda $^{\mathrm{E} 75}$ & Retrospective & 26 & 62 & 96.1 & 92.3 & 223 & 3.8 & NA & 0 & 16 \\
\hline Jaroszewski $^{\mathrm{E} 14}$ & Retrospective & 51 & 65 & 84.3 & 62.7 & 338 & 9.8 & 49 & 5.9 & 11 \\
\hline $\mathrm{Li}^{\mathrm{E} 84}$ & Retrospective & 6 & 55 & 83.3 & 0 & 260 & 0 & 0 & 0 & 17 \\
\hline Noble ${ }^{\mathrm{E} 26}$ & Retrospective & 53 & 66 & 81.1 & 75.5 & 300 & 9.4 & 73.6 & 1.9 & 12 \\
\hline Luketich $^{\mathrm{E} 86}$ & Retrospective & 530 & 64 & 78.3 & 28.5 & NA & 4.3 & NA & 0.9 & 7 \\
\hline Sihag $^{\text {E99 }}$ & Retrospective & 38 & 61.4 & 76.3 & 65.8 & 360 & 0 & 36.8 & 0 & 7 \\
\hline Thomay ${ }^{E 100}$ & Retrospective & 30 & 61 & 86.7 & 100 & 535 & 10 & 86.7 & 0 & 10 \\
\hline de la Fuente ${ }^{\mathrm{E} 6}$ & Retrospective & 50 & 66 & 78 & 70 & 445 & 2 & 28 & 0 & 9 \\
\hline Hernandez ${ }^{\text {E117 }}$ & Prospective & 52 & 65 & 78.8 & 67.3 & 442 & 1.9 & 26.9 & 0 & NA \\
\hline $\mathrm{Guo}^{\mathrm{E} 11}$ & Retrospective & 41 & 60.5 & 78 & NA & 268 & 4.9 & 12 & 0 & 9 \\
\hline Kauppi $^{\mathrm{E} 80}$ & Retrospective & 74 & 66 & 79.2 & 82.4 & 359 & 6.76 & 50 & 2.7 & 13 \\
\hline $\mathrm{Mu}^{\mathrm{E} 93}$ & Retrospective & 52 & 59 & 59.6 & NA & 420 & 7.7 & 21.2 & 1.9 & 17 \\
\hline Tapias $^{\mathrm{E} 40}$ & Retrospective & 80 & 61.5 & 83.8 & 68.8 & 364 & 0 & 37.5 & 0 & 7 \\
\hline Trugeda $^{\mathrm{E} 42}$ & Retrospective & 14 & 56 & 100 & 64.3 & 222 & 28.6 & 42.9 & 0 & 13 \\
\hline $\mathrm{Wu}^{\mathrm{E} 105}$ & Retrospective & 25 & 61 & 64 & 0 & 320 & 4 & 32 & 0 & 13.2 \\
\hline $\mathrm{Xie}^{\mathrm{E} 106}$ & Retrospective & 106 & 63.2 & 70.8 & 0 & 252 & 4.7 & 26.4 & 1.9 & 11.8 \\
\hline Zhao ${ }^{\mathrm{E} 50}$ & Retrospective & 33 & 57.8 & 87.9 & 0 & NA & 0 & NA & 0 & 13 \\
\hline Bongiolatti $^{\mathrm{E} 66}$ & Retrospective & 8 & 64 & NA & NA & 499 & 25 & 25 & 0 & 10 \\
\hline Campbell $^{\mathrm{E} 2}$ & Retrospective & 90 & 62 & 82.2 & 66.7 & 534 & 13.3 & NA & 0 & 12 \\
\hline Mungo $^{\text {E94 }}$ & Retrospective & 52 & 66 & 76.9 & 65.4 & NA & 13.5 & NA & 3.8 & 9 \\
\hline Cerfolio $^{\mathrm{E}}$ & Retrospective & 85 & 63 & 87 & 75 & 360 & 1.3 & 36.4 & 3.5 & 8 \\
\hline Goense $^{\mathrm{E} 8}$ & Retrospective & 167 & 65 & 83.2 & 91.6 & NA & 24 & NA & NA & NA \\
\hline Jeon $^{\text {E1 } 18}$ & Retrospective & 58 & 64.3 & 93.1 & NA & 371.8 & 5.2 & 39.7 & 1.7 & 13.6 \\
\hline $\mathrm{Mei}^{\mathrm{E} 91}$ & Retrospective & 131 & 62.9 & 76.3 & 0 & 252 & 3 & 32 & 2.3 & 11 \\
\hline Salem $^{\mathrm{E} 31}$ & Retrospective & 129 & 67 & 79.8 & 76 & 420 & 3.8 & 22.4 & 1.5 & 11.5 \\
\hline Straatman ${ }^{\mathrm{E} 37}$ & Retrospective & 282 & 62.8 & 77.3 & 90.2 & 333 & 15.2 & 43.6 & 2.1 & 12 \\
\hline Strosberg $^{\mathrm{E} 38}$ & Retrospective & 30 & 64.5 & 70 & 70 & 344 & 3.3 & 23.3 & 3.3 & 8 \\
\hline Ahmadi $^{21}$ & Retrospective & 73 & NA & 86.3 & 100 & 517 & 14 & 74 & 4 & 10 \\
\hline Brown $^{\mathrm{E} 1}$ & Retrospective & 49 & 60.9 & 81.6 & 79.6 & 621 & 2 & NA & 6.1 & 9 \\
\hline Berkelmans $^{\mathrm{E} 59}$ & Retrospective & 114 & 66 & 86 & 90 & NA & 21 & 72.8 & 0.9 & 15 \\
\hline Egberts $^{\mathrm{E} 115}$ & Retrospective & 75 & 66 & 68 & 78.7 & 392 & 16 & 69.3 & 3 & 16 \\
\hline $\operatorname{Liu}^{\mathrm{E} 110}$ & Retrospective & 122 & 61.4 & 78.7 & NA & 272 & 1.6 & 22.1 & NA & NA \\
\hline $\operatorname{Pan}^{\mathrm{E} 95}$ & Retrospective & 36 & 64.5 & NA & NA & NA & 0 & 25 & 0 & 11 \\
\hline Zhang $^{\mathrm{E} 112}$ & Retrospective & 90 & 62.9 & 75.6 & 0 & 268 & 5.6 & 25.6 & 1.1 & 14 \\
\hline Berlth $^{\mathrm{E} 60}$ & Retrospective & 20 & 61 & 95 & 70 & 350 & 15 & 55 & 5 & 13 \\
\hline Dalton $^{\mathrm{E} 5}$ & Retrospective & 40 & 63 & 80 & 90 & 374 & 5 & 47.5 & 2.5 & 9 \\
\hline Grimminger $^{\mathrm{E} 74}$ & Retrospective & 50 & 62 & 82 & 70 & 338 & 14 & NA & 0 & 19 \\
\hline Kang $^{\text {E16 }}$ & Retrospective & 215 & 62.9 & 83.3 & 0 & 296.7 & 2.8 & 27.9 & 0.5 & 20 \\
\hline Stenstra ${ }^{\mathrm{E} 35}$ & Retrospective & 164 & 64 & 79.9 & NA & 270 & 14.6 & 40.2 & 3.7 & 11 \\
\hline $\mathrm{Wu}^{\mathrm{E} 48}$ & Prospective & 67 & 62 & 82 & NA & NA & 1.5 & NA & 1.5 & 15 \\
\hline
\end{tabular}


TABLE E3. Continued

\begin{tabular}{|c|c|c|c|c|c|c|c|c|c|c|}
\hline $\begin{array}{l}\text { First author } \\
\text { reference }\end{array}$ & Design & $\begin{array}{c}\text { Patient } \\
\text { N }\end{array}$ & $\begin{array}{c}\text { Median } \\
\text { age, years }\end{array}$ & $\begin{array}{r}\text { Male } \\
\text { sex, \% }\end{array}$ & $\begin{array}{c}\text { Neoadjuvant } \\
\text { therapy, \% }\end{array}$ & $\begin{array}{c}\text { Mean } \\
\text { operative } \\
\text { time, minutes }\end{array}$ & $\begin{array}{c}\text { Anastomotic } \\
\text { leak, \% }\end{array}$ & $\begin{array}{c}\text { Overall } \\
\text { morbidity, \% }\end{array}$ & $\begin{array}{c}\text { Mortality, } \\
\% \\
\end{array}$ & $\begin{array}{c}\text { Median } \\
\text { LOS, } \\
\text { days }\end{array}$ \\
\hline van Workum ${ }^{\mathrm{E} 43}$ & Retrospective & 561 & 65 & 84.1 & 93.6 & 268 & 14.4 & 61.5 & 2.3 & 11 \\
\hline Zhan $^{\mathrm{E} 49}$ & Retrospective & 257 & 65.4 & 74.3 & NA & 307 & 6.6 & 30.4 & 0.4 & 13.7 \\
\hline Kukar $^{\text {E51 }}$ & Retrospective & 121 & 66 & 56.2 & 71.9 & 463 & 5 & 52.9 & 2.5 & 8 \\
\hline Meredith $^{\mathrm{E} 92}$ & Retrospective & 239 & 64 & 81.2 & 77.4 & 354 & 3.3 & 25.9 & 1.7 & 9 \\
\hline Pötscher ${ }^{\mathrm{E} 120}$ & Retrospective & 11 & NA & NA & NA & 389 & 18.2 & 27.3 & NA & 16.7 \\
\hline Souche $\mathrm{E}^{\mathrm{E} 3}$ & Retrospective & 58 & 62 & 65.5 & 87.9 & 380 & 31 & NA & 0 & 19 \\
\hline Tagkalos $^{\mathrm{E54}}$ & Retrospective & 100 & 63 & NA & 77 & 352 & 15 & 32 & 3 & 31 \\
\hline Valmasoni $^{\mathrm{E} 101}$ & Retrospective & 10 & 60.4 & 90 & 60 & 342 & 10 & 50 & 0 & NA \\
\hline Wang $^{\text {E44 }}$ & Retrospective & 37 & 62.7 & 94.6 & 21.6 & 340 & 8.1 & 45.9 & 0 & 10 \\
\hline Wang $^{\mathrm{E} 140}$ & Retrospective & 216 & 61 & 83.8 & 0 & 265.5 & 6.9 & 50.9 & 2.3 & 13 \\
\hline Wang $^{\mathrm{E} 55}$ & Retrospective & 31 & 59.7 & 87 & 0 & 387 & 6.5 & 19.4 & 0 & 12 \\
\hline Wang $^{\mathrm{E} 121}$ & Retrospective & 24 & 63 & 87.5 & 16.7 & 352.5 & NA & 12.5 & 0 & 11 \\
\hline $\operatorname{Yin}^{\mathrm{E} 107}$ & Retrospective & 20 & 64.5 & 70 & NA & 267 & 5 & 10 & 0 & 12.8 \\
\hline Zhang $^{\mathrm{E} 56}$ & Retrospective & 77 & 61.6 & 88.3 & 20.8 & 349 & 6.5 & 39 & 0 & 12.2 \\
\hline Zhang $^{\text {E111 }}$ & Retrospective & 76 & 61.8 & 77.3 & 0 & 303.5 & 11.4 & 39.3 & 1.6 & 9 \\
\hline Awad $^{\mathrm{E} 113}$ & Retrospective & 100 & 65.1 & 80 & 88 & 384 & 6 & 40 & 3 & 10.3 \\
\hline Berlth $^{\text {E114 }}$ & Retrospective & 100 & 66 & 84 & 84 & NA & 5 & NA & 1 & 11 \\
\hline $\mathrm{Gao}^{\mathrm{E} 116}$ & Retrospective & 34 & 62 & 91.2 & NA & NA & 2.9 & 29.4 & 0 & 10 \\
\hline Merritt $^{\mathrm{E} 119}$ & Retrospective & 173 & 62.1 & 80.3 & NA & NA & 4 & 40.5 & 1.2 & 8 \\
\hline Shen $^{\mathrm{E} 52}$ & Retrospective & 102 & 55 & 70.6 & NA & 323.4 & 5.9 & NA & NA & 11.5 \\
\hline Zhang $^{\mathrm{E} 122}$ & Retrospective & 590 & 61.1 & 83.9 & NA & NA & NA & 17.6 & 1.4 & NA \\
\hline
\end{tabular}

